\title{
DET EKSPERIMENTERENDE FALLESSKAB \\ - Børn og voksnes leg med medier og teknologi
}

\section{Ole Caprani}

\section{Lektor}

Datalogisk Institut, Aarhus Universitet.

\section{Klaus Thestrup}

Ph.d.-studerende Institut for Informations- og Medievidenskab, Aarhus Universitet
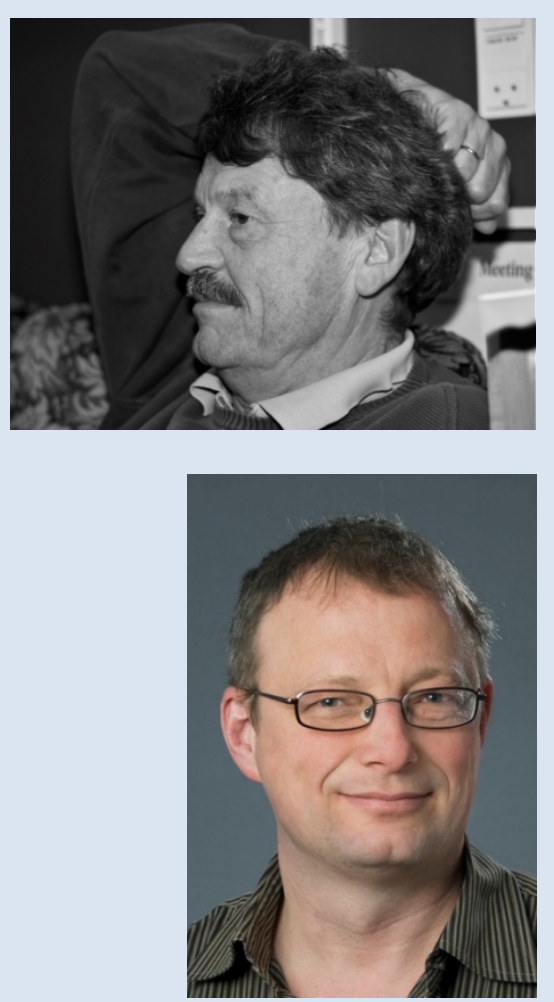


\section{Abstract}

Siden 2002 har vi sammen med børn, pædagoger og lærere leget og eksperimenteret med medier og teknologi. I daginstitution eller skole har vi sammen med børn mellem fire og ni år skilt gamle computere ad til sidste skrue og lavet nyt legetøj ud af dem, taget hundredvis af billeder med digitale kameraer og leget med professionel blue-screen teknologi. Midt i børnenes hverdag har vi i en række mindre projekter afprøvet og analyseret alt fra helt konkrete pædagogiske metoder til principper for, hvordan børn og voksnes fælles møde med medier og teknologi kan tage form. Denne artikel trækker eksempler og begreber ud af denne forskningspraksis og samler det i en pædagogik: Det eksperimenterende fællesskab.

\section{Mødet med medier og teknologi}

I 2007 og 2008 fik børn i de daværende børnehaveklasser på

Katrinebjergskolen mulighed for at møde såkaldt blue-screen teknologi på Center for Avanceret Visualisering og Interaktion under Århus Universitet (CAVI). Blue-screen-teknologien gør det muligt at lave billeder, hvor studieværter eller skuespillere befinder sig på månen, i en ørken eller inde i en computer. Studieværter eller skuespillere placeres fysisk i et blåt studie, et ensfarvet blåt rum, hvor kameraer optager deres ageren. I et billedredigeringsrum ved siden af det blå rum kan den blå farve i baggrunden af de optagne billeder af studieværter eller skuespillere erstattes af billeder f.eks. fra månen, og resultatet er et billede, hvor det ser ud som om de filmede personer befinder sig på månen. Personerne i det blå rum kan se det redigerede billede på et stort lærred på den væg i det blå rum som ikke er i kamerabilledet. På den måde kan personerne i det blå rum se sig selv agere på månen. 


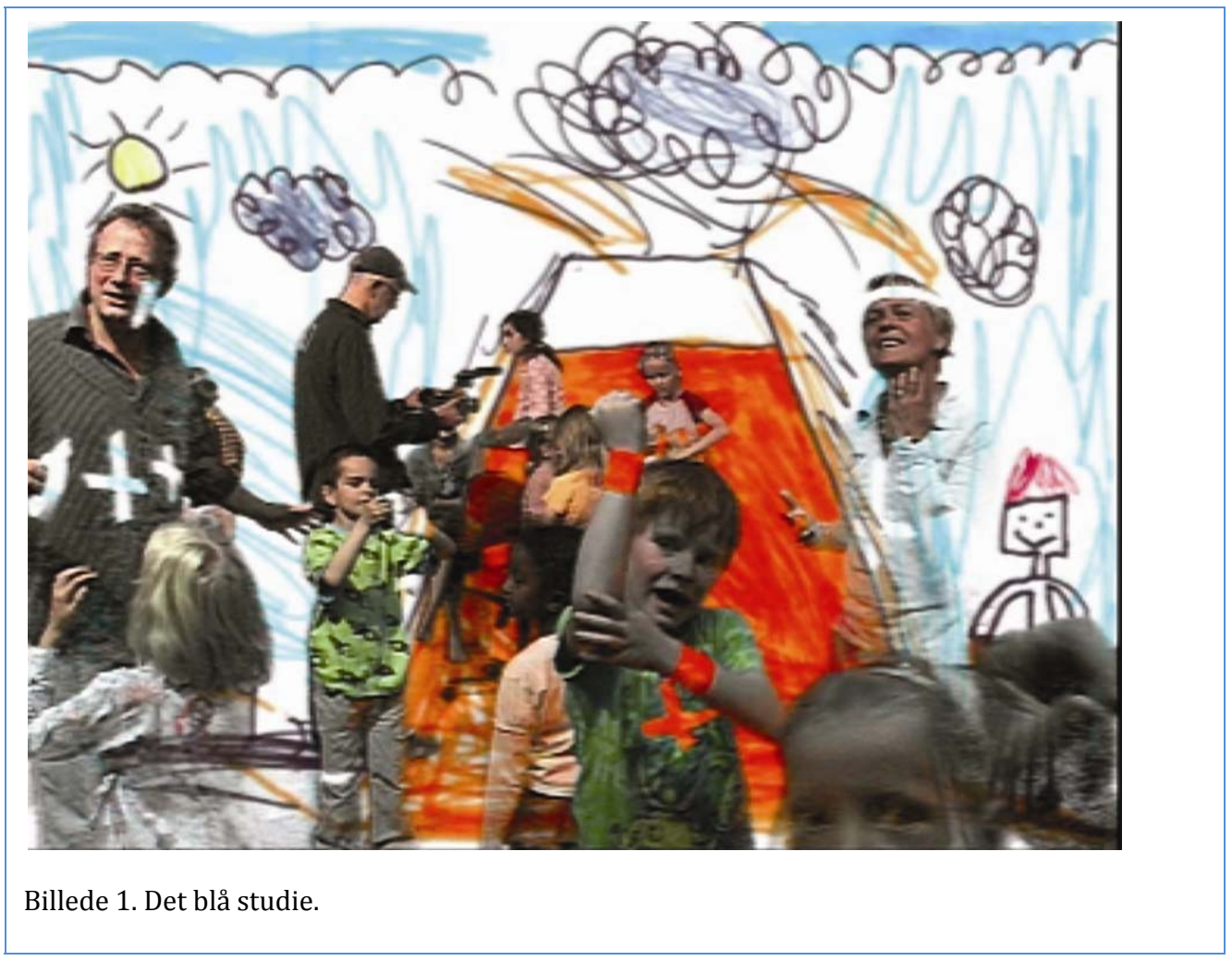

Besøget på CAVI var det seneste i den række af projekter, vi de sidste syv år har gennemført for at undersøge, hvordan medier og teknologi kan gøres tilgængelige for yngre børn og voksne i daginstitutioner og skoler. Besøget på CAVI kunne have været tilrettelagt som et kort besøg, hvor en af CAVI's omvisere kunne have demonstreret og forklaret, hvad CAVI bruger bluescreen-teknologien til. I stedet for et sådant besøg, hvor udgangspunktet var den nuværende brug af teknologien, ønskede vi at tilrettelægge besøget, så det var muligt for børn og voksne i fællesskab at undersøge teknologiens muligheder igennem eksperimenter, leg og fortælling.

I denne artikel præsenterer vi den pædagogik, som lå bag tilrettelæggelsen af børnehaveklassernes besøg på CAVI. Vi gør det ved at beskrive, hvordan elementerne i en sådan pædagogik er blevet opdaget og undersøgt igennem de projekter, vi har gennemført de sidste syv år. Beskrivelsen tager udgangspunkt i udvalgte konkrete projekter og præsenteres i fortællende form, så læseren kan kigge os over skulderen og få indsigt i den praksis, vi har arbejdet i. De udvalgte projekter hedder Robotterne går sig en tur, 
Opfind dit eget legetøj, Mikrobyen og CAVI-projektet, som kom til at hedde Det blå rum.

I projekterne har vi indsamlet og analyseret informationer i form af logbøger, tegninger, fotos og videoklip. Vi har løbende diskuteret projekterne med de lærere og pædagoger, som har deltaget i projekterne. Fra begyndelsen har vores undersøgelser været praktisk pædagogik, hvor vi er trådt ind og har været med til at planlægge og selv afprøve den pædagogik, vi har undersøgt. Vi har deltaget i og været med til skabe de lege og fortællinger, der er opstået undervejs i de forskellige projekter. For børnene er de forskellige projekter ikke en tilsyneladende pædagogik, men en konkret hverdag af stor vigtighed for deres liv nu og her. Vi har valgt at tage børnene så alvorligt, at vores undersøgelser har været en del af deres institutions- og skoleliv. Børnene har deltaget i vore undersøgelser, og vi har kvitteret ved at gøre vores deltagelse til pædagogik nu og her. Vi har i stigende grad arbejdet med at få de forskellige indsamlede informationer til med det samme at indgå i et betydningsskabende kredsløb i de forskellige projekter. I børnehaveklassernes møde med blue-screenteknologi så børnene således hver morgen billeder og videoklip fra dagene før. Billeder og videoklip er vores informationer om projektet, men de indgik også i de fælles samtaler og drøftelser om blue-screen-teknologi og hvad vi, børnene, lærerne og pædagogerne, nu skulle fortsætte med at undersøge.

Samlet har vi i fællesskab med lærere og pædagoger på Katrinebjergskolen i Århus gennemført tretten projekter i børnehaveklasser, de små klasser og i SFO-afdelingen "Blæksprutten" placeret på skolen. De ti af disse har typisk varet en hel uge, et enkelt projekt har varet to uger, mens to projekter har været organiseret med en dag om ugen over en periode på knap to måneder. I perioden 2002 - 2005 etablerede vi og arbejdede sammen med en tværfaglig udviklingsgruppe bestående af lærere, pædagoger, seminarielærere og folk fra kultursektoren. Dette samarbejde sluttede i efterårsferien 2005 med udstillingen og aktiviteten Teknikleg på Steno Museet ved Aarhus Universitet. 
Foreløbig har vore undersøgelser resulteret i den narrative

dokumentarvideo "Robotterne går sig en tur", (Henningsen 2002), hæfterne "Når robotterne går sig en tur" (Jeppesen og Wøldiche 2002) og "Teknikleg - et inspirationskatalog for opfindsomme børn og voksne" (Caprani og Thestrup 2005), fotoserien "Opfind dit eget legetøj" (Poulsgaard, 2004) og adskillige foredrag, workshops og artikler, der henvender sig til pædagoger og lærere. Endelig er der blevet produceret en visuel dagbog til de børn, der deltog i et af besøgene på CAVI (Caprani, Henningsen og Thestrup, 2007).

\section{Robotterne går sig en tur}

I 2002 planlagde og gennemførte vi en emneuge i en børnehaveklasse på Katrinebjergskolen. Emnet var robotter. Emnet udsprang af et ønske om at undersøge, hvordan LEGOs robotbyggesæt kunne bruges af børn i en børnehaveklasse. Vi valgte at bruge byggesættet LEGO Mindstorms Robotic Discovery Set (\#9735). Ud over sædvanlige LEGO-elementer som klodser, tandhjul, akser og nitter består robotbyggesættet af motorer, lamper, ledninger, tryksensorer og en kontrolenhed kaldet Scout. En Scout er på størrelse med en voksenhånd. Den er blå med et display, fire knapper uden om displayet, en indbygget lysføler og en højtaler. En Scout kan forbindes med motorer og hjul, så hjulene kan køre, styret af kontrolenheden. En Scout kan forbindes med tryksensorer, så kontrolenheden kan reagere på tryk f.eks. på en kofanger, og kontrolenheden kan på den måde få en bil til at bakke, når den støder ind i en forhindring. Når Scout er aktiv, laver den forskellige lyde f.eks. insektlignende lyde. 


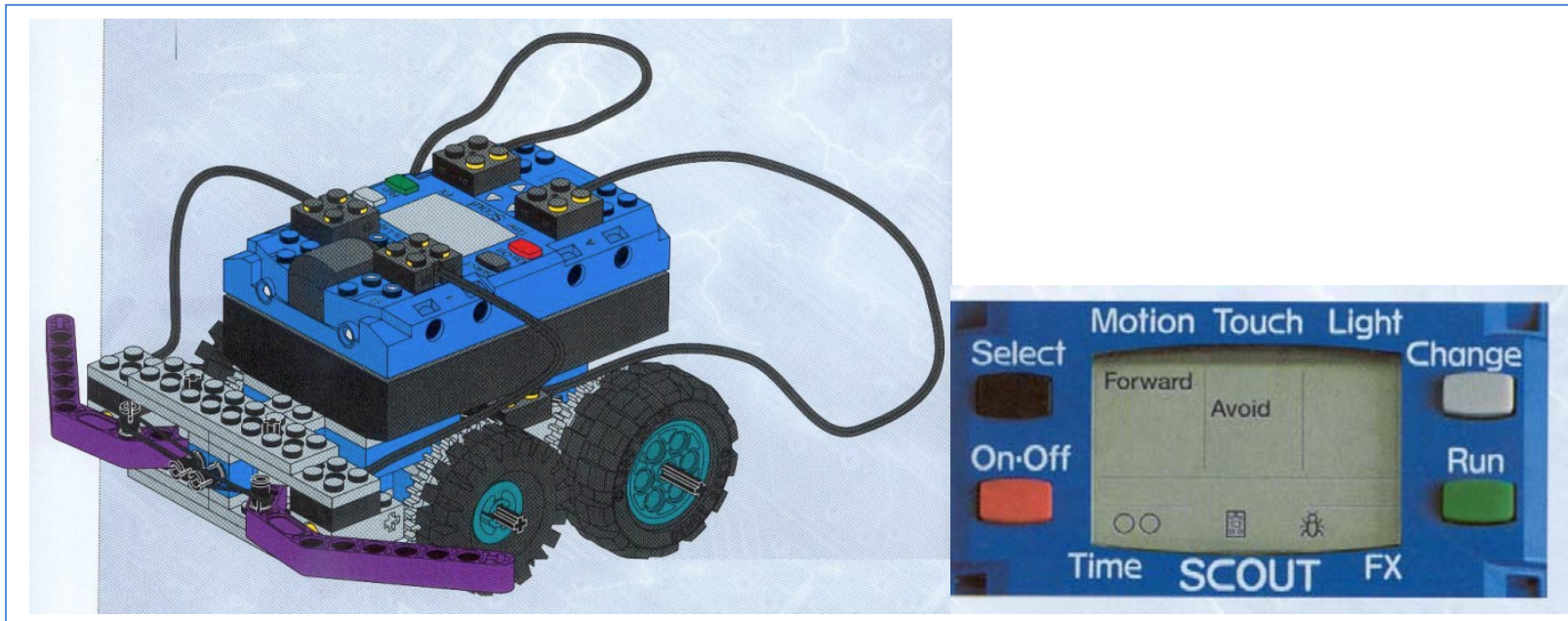

Billede 1. En Scout-kontrolleret LEGO-robot. Motorer og trykfølere er forbundet til kontrolenheden med LEGOledninger. Kontrolenhedens display og fire knapper gør det muligt at vælge robottens handlinger. Her er det valgt, at den hele tiden kører ligeud, indtil den støder ind i en forhindring. Sker det, bakker den og drejer væk. I legens prøvensig-frem- undersøgelse af handlemuligheder fandt børn og voksne hurtigt ud af at bruge kanpperne.

Det særlige ved Scout i forhold til en anden af LEGO Mindstorms

kontrolenheder, RCX, er, at den kan bruges på mangfoldige måder uden at være i forbindelse med en computer. Når en Scout tændes, vises en menu, hvor de enkelte indgange vælges ved at trykke på knapperne, og næsten uanset i hvilken rækkefølge der bliver trykket, vil Scout gøre noget og f.eks. få en bil til at bevæge sig rundt på gulvet. Det var grunden til, at vi valgte Scout frem for RCX. Da emnet var robotter og ikke LEGO-bygning, havde vi på forhånd bygget otte Scout-styrede insektlignende LEGO-robotter. Det betød, at vi kunne starte med fungerende robotter, og på den måde kunne vi sammen med børnene f.eks. undersøge, hvad der skete ved de forskellige menuvalg.

Brugen af LEGOs robotbyggesæt som det konkrete udgangspunkt for børns møde med teknologi kom til at få stor betydning for den pædagogik, vi siden har udviklet og formuleret. Teknologien befandt sig i rummet og ikke på en skærm. Den kunne flyttes derhen, hvor den skulle bruges. F.eks. blev et par Scout-robotter båret ned i en mørk kælder, så vi kunne undersøge, hvordan robotterne reagerede, når vi lyste på dem med en lommelygte. Desuden var dele af teknologiens muligheder nemt tilgængelige. Med ganske få knaptryk ville robotterne kunne fungere og kunne bruges i en leg som et stykke legetøj. F.eks. indrettede en pige et hjem med en tyverialarm 
til en Scout-robot. Hvis en fremmed robot trængte ind gennem hjemmets dør, stødte den på en klokke, som hang i dørkarmen. Klokken ringede, og den fremmede robot var afsløret. Et enkelt tryk på startknappen fik den fremmede robot til at køre ind af døren til hjemmet og aktivere alarmen. Tre drenge kravlede ind i en mørk hule og lod Scout-robotten ruge en bordtennisbold ud. Med få knaptryk fik drengene robotten til at lave lyde og lyse, når de lyste på den. En Scout var også i sig selv en klods, som man kunne sætte andre klodser på. Det var muligt at bygge videre på Scoutklodsen også uden at skulle tænke på motorer og bevægelser. F.eks. lavede et barn en Fødselsdags-Robot ved at bygge små LEGO-figurer og flag på Scout klodsen.

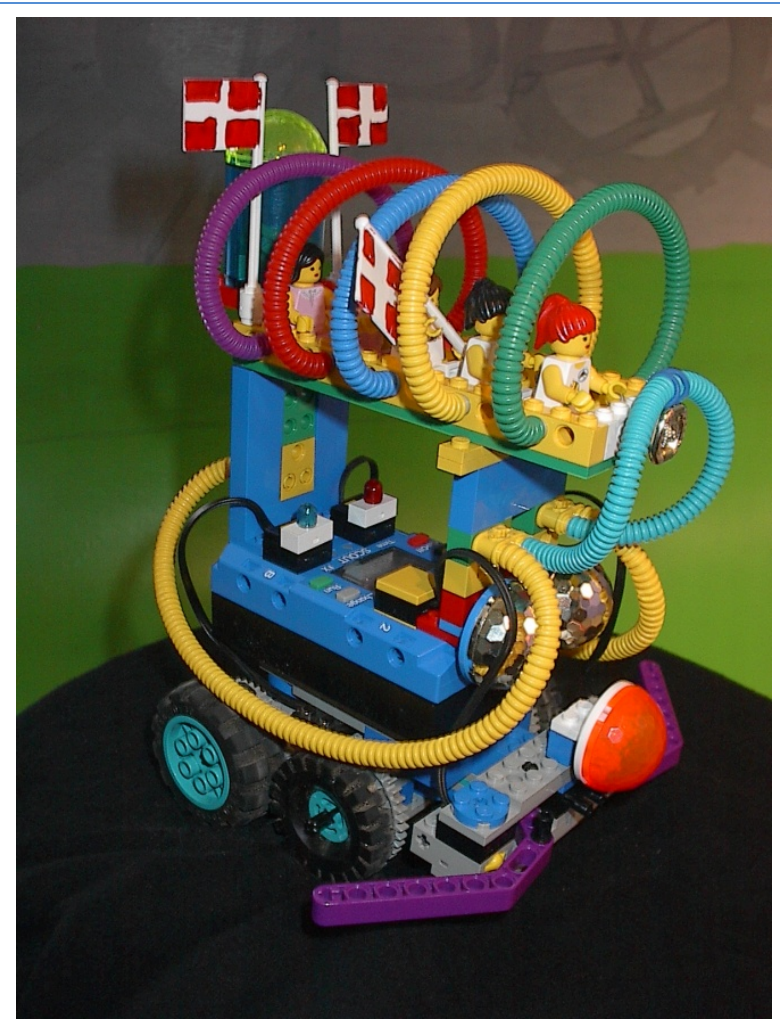

Billede 3. Fødselsdags-Robot. Den basale Scout-kontrollerede bil er påmonteret flag, passagerer og små LEGO-lamper sat på ledningerne, så de blinker når robotten kører.

Teknologien er til rådighed for børnene i deres leg, fordi den ikke kræver mere end nogle få tryk på få knapper for at få robotten til umiddelbart at gøre noget. Dette krav til en teknologis muligheder kunne vi lidt spidsformuleret kalde Et tryk - En leg. 
På det tidspunkt, hvor vi introducerede disse Scout-robotter, vidste vi ikke ret meget om, hvordan en pædagogik kunne udformes så børn og voksne i fællesskab kunne undersøge Scout-robotternes muligheder, men i ugens løb fik vi gradvist fastlagt en pædagogisk struktur og afprøvet pædagogiske metoder og principper. Det skete i tæt samspil med de lærere og pædagoger, som vi arbejdede sammen med. Vi eksperimenterede med metoder, som øjeblikkeligt fik konsekvenser og gav muligheder i forhold til de børn, vi var sammen med. F.eks. dukkede de to lege med bordtennisbolden og tyverialarmen op, fordi vi gav børnene mulighed for selv at lege med Scout-robotterne i et rum i en SFO, hvor børnene selv definerede, hvad de ville lave, hvor længe og hvordan. Vi kastede også Scout robotter ned fra træer fra forskellige højder og lod dem køre i sandkassen og fandt på den måde helt kontant ud af, hvad de var beregnet til at holde til, og hvad de ikke kunne klare. Vi fik også den pædagogiske struktur til at inkludere den legeplads, som ellers er et af de rum i SFO og skolen, hvor børnene selv organiserede tid, sted og indhold.

Vi diskuterede, hvordan vi skulle indrette de rum, vi brugte. Vi blev enige om at stille LEGO-klodserne i opbevaringskasser af plastic på gulvet midt i klasseværelset, så alle kunne nå dem fra begge sider. 


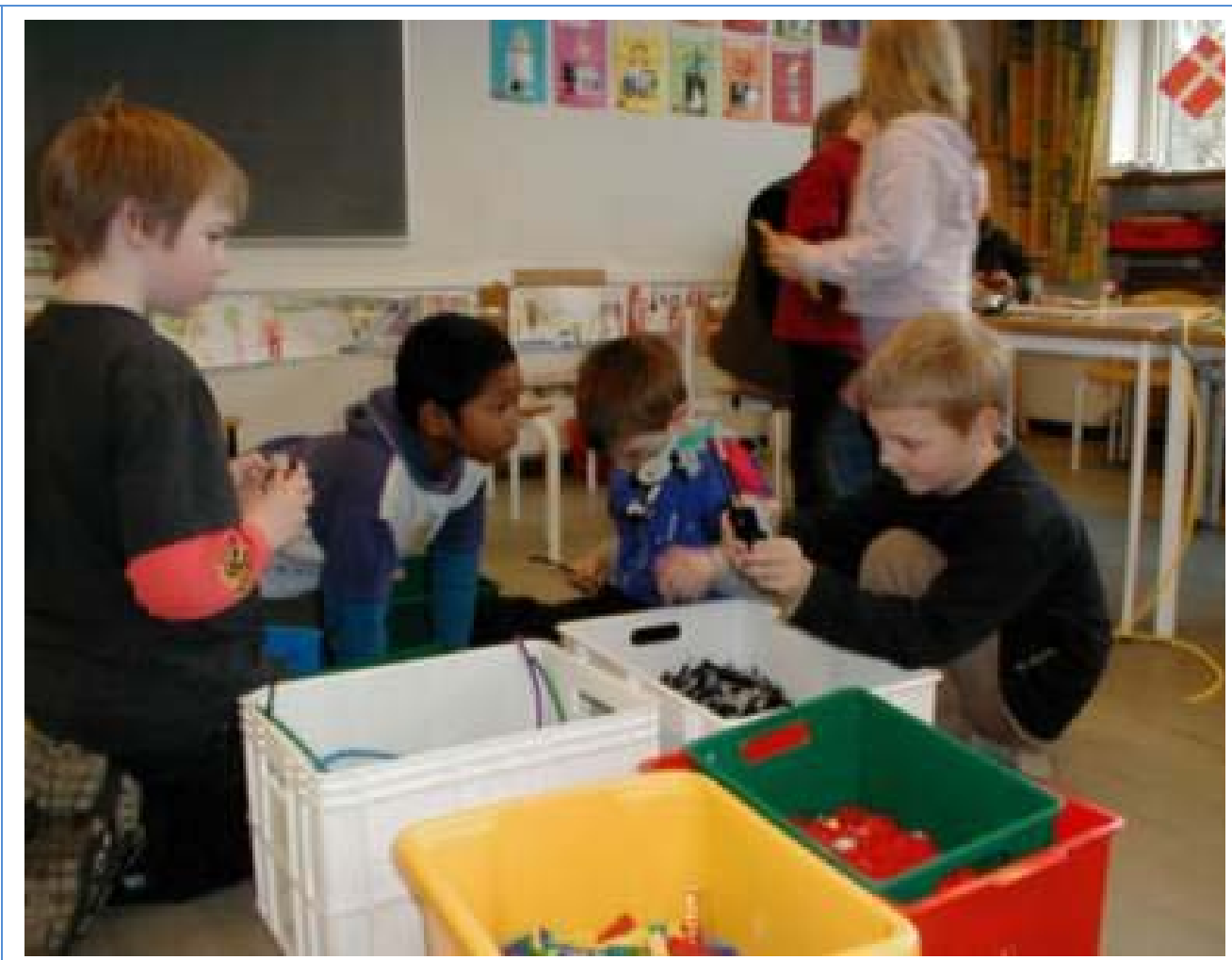

Billede 4. Klasseværelset som værksted med de forskellige LEGO-elementer i plastkasser anbragt midt i rummet.

Vi fulgte hermed det pædagogiske princip, som børnehaveklasselederne i forvejen fulgte, og som handlede om at ændre lokalet efter den aktuelle situation. I dette tilfælde blev klasseværelset et værksted. Borde og stole var ikke beregnet til at sidde ved, men til at bygge ved. Børnene fik mulighed for selv at finde det, de skulle bruge. Børnene kunne bygge og lege med robotter med dem, de ville blandt de andre børn. Det medførte bl.a., at hvis en af de voksne fortalte eller viste nogle få børn en teknisk mulighed, varede det ikke længe, før andre børn også vidste det. Det var blevet fortalt videre, eller andre børn havde set, hvordan man gjorde. Det kan forekomme enkelt, når det beskrives her, men vi havde faktisk fået fat i et element af den måde, børnene omgås hinanden som gruppe i deres legekultur (Mouritsen, 1996). De fordelte sig i små skiftende grupper, gik rundt i lokalet og så, hvad hinanden foretog sig. Dette kalder vi Lur de andre kunsten af. 


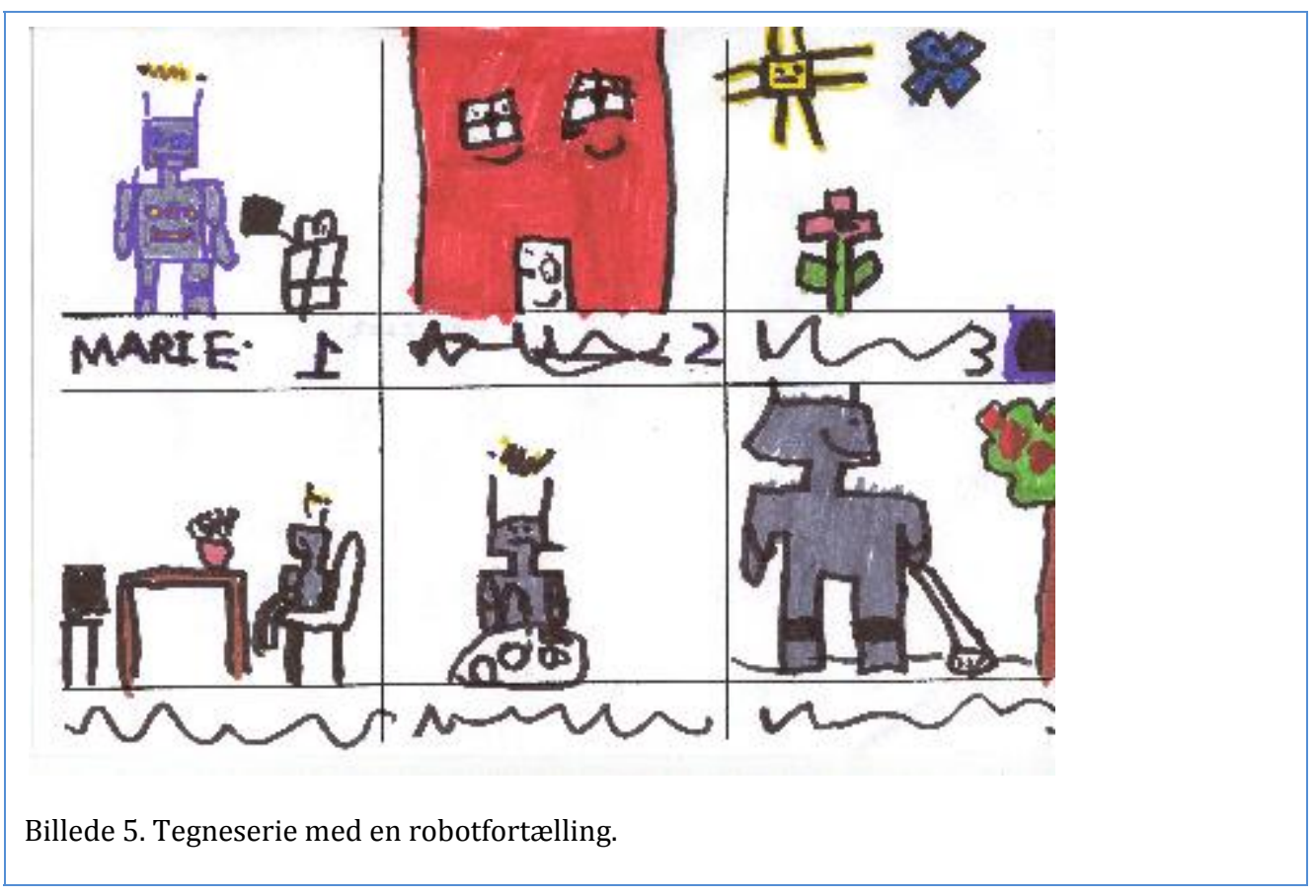

Vi kombinerede børnenes undersøgelse af LEGO-robotterne med traditionelle medier. Vi lavede tegneserier med robotter i hovedrollen. Igen anvendte vi her en eksisterende pædagogisk metode fra børnehaveklassens hverdag. I fire eller seks felter på et A4-ark på langs skulle børnene tegne små fortællinger med robotter. Vi lavede forskellige lege og øvelser sammen med børnene hentet fra dramapædagogikkens lager af øvelser. Et eksempel er en dramaøvelse om at styre robotter, hvor børnene var sammen to og to. Den ene var en robot, og den anden havde en fjernbetjening. Øvelsen gik ud på at prøve at styre en robot, der ikke nødvendigvis ville lade sig styre. Klasseværelset blev her lavet om til et dramarum, hvor forholdet mellem menneske og maskine blev undersøgt med kroppen som værktøj.

Vi fortalte historier for og med børnene om det, de og vi foretog os. Mens de spiste madpakker fortalte vi historier, hvor vi brugte figurer, de havde lavet, og elementer af det, vi havde snakket om eller prøvet i løbet af formiddagen. Fortællingen blev udviklet undervejs, og børnene fik mulighed for at foreslå, hvad der skulle med i fortællingen eller ændre på fortællingens retning undervejs. Et eksempel på dette er fortællingen om De døde børns klasseværelse, som byggede på noget, børnene havde sagt om 
kælderen, mens vi var nede og lyse på robotterne med lommelygterne. Det viste sig at være en form for vandrehistorie, som børnene i indskolingen fortalte hinanden, og som ingen voksne omkring dem tilsyneladende kendte til. Denne vandrehistorie byggede vi videre på i fortællingen. Det endte endda med, at vi byggede en robot, der skulle kunne køre ind i kælderen og undersøge rummet, som børnene fortalte var De døde børns klasseværelse. Under spisningen blev klasseværelset et fortælleteater, og fortællingen blev et orienteringspunkt, som gjorde det muligt for børn og voksne sammen at kigge bagud på det, vi havde lavet og få ideer til, hvad vi kunne lave.

I ugens løb mødte børn og voksne robotteknologi med robotbyggesæt, fortælleteknikker og dramaøvelser som midler. Konkrete robotter blev bygget, bygget om, eksperimenteret og leget med. Emnet robotter blev undersøgt igennem legen, dramaøvelser og fortællinger. Den pædagogiske struktur med klasseværelset som værksted, fortælleteater og dramarum gjorde det muligt at etablere en kombination af konstruktion, leg og fortælling, så børn og voksne i fællesskab kunne skabe viden, sammenhæng, betydning og mening omkring det, vi var sammen om, robotteknologi. Den pædagogiske struktur gav plads til, at børnene kunne udfolde sig, som de plejer i deres egen legekultur, og det valgte robotbyggesæt gjorde det let for børnene at konstruere og eksperimentere med konkrete robotter og inddrage de konkrete robotter i deres leg og fortællinger. Skiftet imellem konstruktion af konkrete robotter og fortællinger om robotter minder om den lethed, hvormed børn i deres legekultur bevæger sig imellem realplan og fiktionsplan, (Mouritsen, 1996).

\section{Opfind dit eget legetøj}

Dansk Naturvidenskabsfestival 2004 havde temaet "Opdagelser og opfindelser". Det inspirerede os til at lave et projekt i en første klasse, hvor børnene skulle opfinde og opdage: Opfinde legetøj og opdage lege med legetøjet. I stedet for LEGO, som var det vigtigste materiale i Robotterne går sig en tur, indførte vi teknologisk skrot, kasseret legetøj og gaffatape som det nye materiale. Ideen var, at børnene skulle skille kasserede computere 
og kasseret legetøj ad og bruge gaffatape til at sætte det sammen som prototyper på nyt legetøj. De skulle finde på navne og fortællinger til legetøjet og til sidst gruppevis lave en legetøjsbutik, hvor legetøjet skulle præsenteres med plakater. Plakaterne skulle bestå af en række digitale billeder af legetøjet, de selv havde taget. Hvilket legetøj, de ville lave, hvordan det skulle se ud, og hvad det skulle kunne, var ikke bestemt på forhånd af os eller de lærere, som deltog i projektet.

Dette projekt gav anledning til en række nye pædagogiske overvejelser. Klasseværelset skulle stadig være et værksted som i Robotterne går sig en tur, og borde og gulv skulle være de steder, hvor børnene kunne skille teknologi og legetøj ad. Men helt konkret måtte vi udvide antallet af kasser, for at børnene kunne få let og overskuelig adgang til de nye materialer. Computerskrot op til størrelsen af tastaturer kom i hvide kasser. Hele stationære computere og printere blev stillet i et hjørne og kunne hentes. Legetøj kom i grønne kasser. Det kunne være enhver slags legetøj, men der var en del bamser og andre tøjdyr. Sakse, skruetrækkere og gaffatape kom i røde kasser.

Vi diskuterede, hvordan vi skulle introducere børnene til, hvad ideen med projektet var, og især hvad det ville sige at opfinde. Vi blev enige om at demonstrere for børnene, hvad det gik ud på. Vi stillede os op foran børnene og fortalte om de forskellige kasser, og hvad der var i dem. Derefter hentede vi selv stumper frem fra kasserne og lavede nyt legetøj, mens børnene så på. Vi havde ikke forberedt, hvad vi ville opfinde på forhånd. For øjnene af børnene konstruerede vi en brødrister med hjul fra en bil, et rør som kanon og en Barbiedukke ovenpå. Den blev straks af børnene kaldt for en Barbie-shooter, og vi lod den med det samme indgå i en fortælling sammen med en figur fra en af de grønne kasser. 


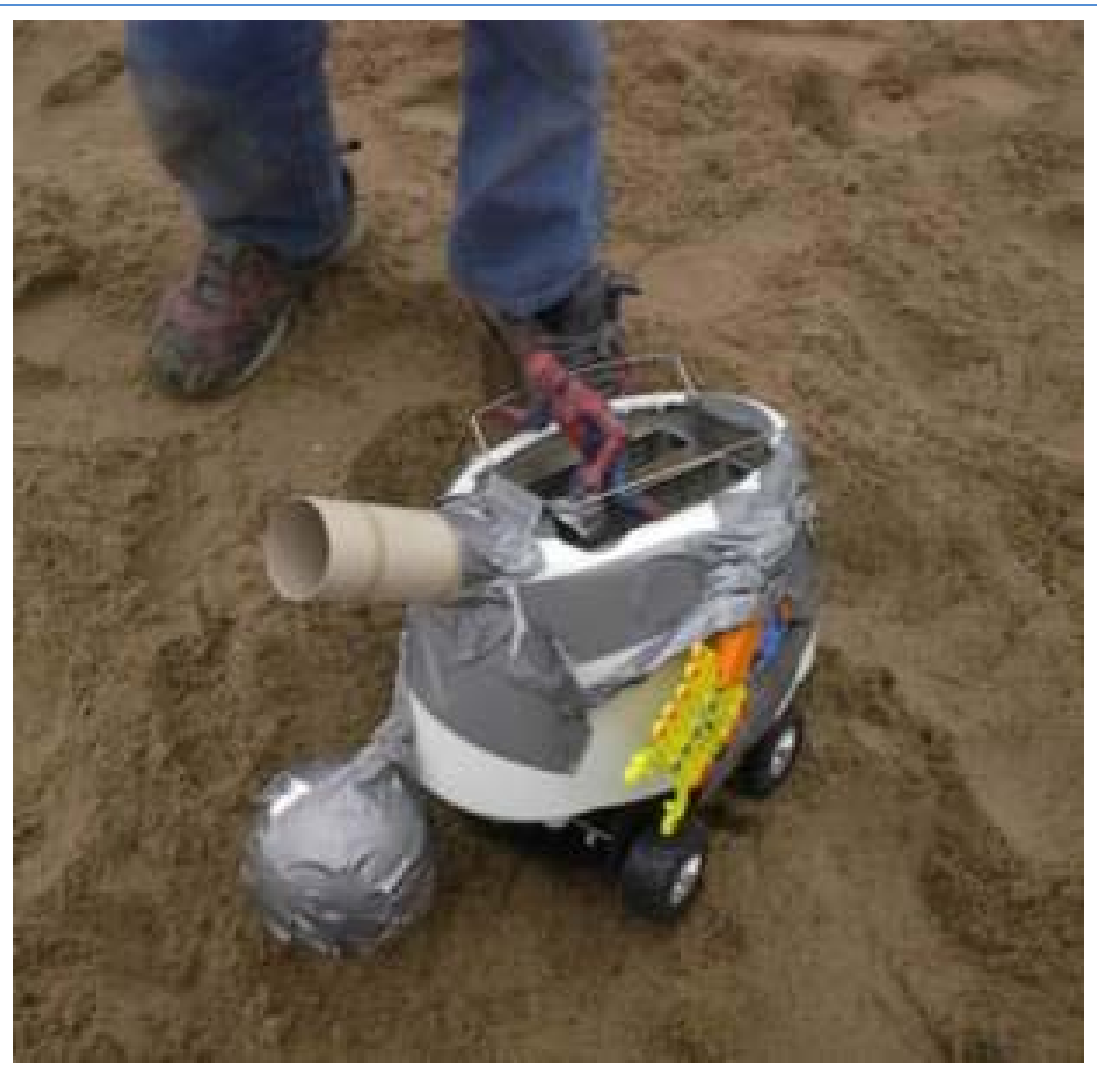

Billede 6. Et senere stadie af Barbie-shooteren. Nu er Barbiedukken erstattet af en actionmand, og der er anbragt en kampkugle foran.

Efter introduktionen og opstillingen af kasser havde børnene ingen vanskeligheder med at gå i gang. De spredte sig mellem kasserne og fandt det, de skulle bruge. Nogen gik i gang med at skille skrottet ad, andre gik i gang med at finde bamser, men i løbet af den første formiddag havde alle haft en skruetrækker i hånden og var i gang med skille noget ad og havde med gaffatape sat noget sammen. I løbet af ugen blev der både bygget store og små ting.

Et eksempel på et lille stykke legetøj var Kaninkameraet. Det bestod af et sort kaninhoved, som var sat fast på et rødt plastickamera med gaffatape. Kaninkameraet var en del af en lang række konstruktioner, hvor en stump af en teknologi blev sat sammen med en stump legetøj. Ideen opstod, da en gruppe piger kom hen og spurgte, om det nu var rigtigt, at de måtte klippe bamserne i stykker. Da det blev bekræftet, gik de i gang med at klippe hovederne af tøjdyrene og sætte dem fast med gaffatape på computermus, 
printplader eller skærme. I løbet af meget kort tid spredte ideen sig i børnegruppen og det blev en af de ting, der prægede projektet.

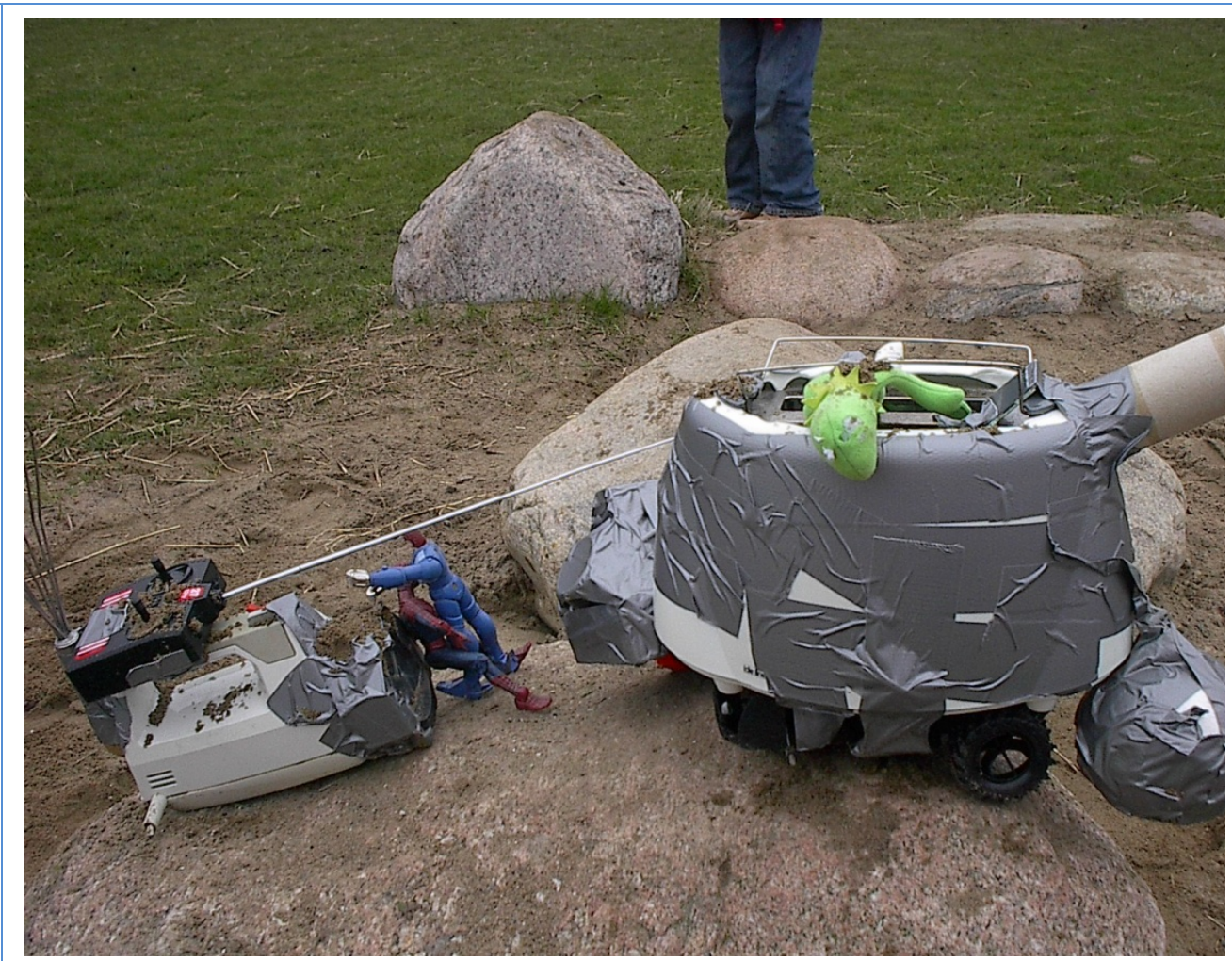

Billede 7. En håndmikser med fjernbetjening tager kampen op med Babie- shooteren.

Et eksempel på et større stykke legetøj var en form for brætspil inspireret af computerspil, som nogle af børnene spillede på det tidspunkt. Det bestod af musemåtter lagt ud ved siden af hinanden på to skoleborde, der var sat sammen over for hinanden. Gaffatapen var vejbaner, og computermusene var køretøjer, der kørte rundt på spillefladen. Der var steder, hvor man kunne tanke ny energi, og hvor man kunne blive angrebet af monstre og miste energi. Det var også muligt at komme op i "level" og skifte verden. Det sidste foregik ved at pege på nogle malede kugler, der hang hen over hovederne på børnene, og som var verdener i det univers, spillet foregik i. 


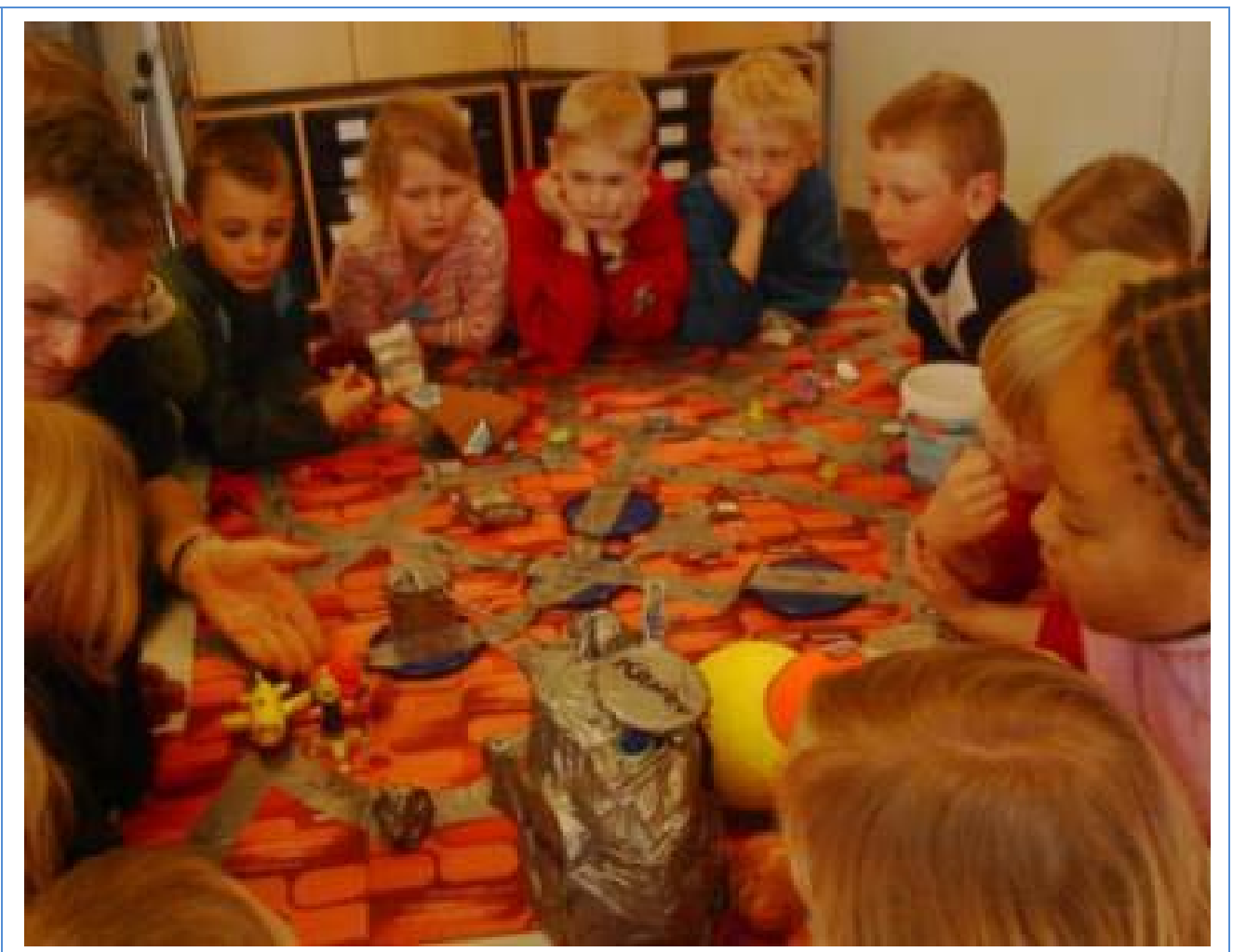

Billede 8. Brætspil af computermusemåtter med gaffatape veje og spilfigurer bl.a. lavet af computermus.

Spillet er opbygget ved brug af de materialer, vi havde medbragt i kasser, men også under brug af traditionelle materialer. Verdenerne i spiluniverset var malede flamingokugler. Computermusene fik tegnet døre og vinduer på med tuscher. Spillet er på en gang en kopi af computerspil, børnene havde mødt før og en ny version. Det var et platformspil, men i en fysisk udgave liggende på et bord med et helt univers ovenover. Der var baner og en enkel grunddramaturgi med onde og gode, men der var på den anden side ingen faste regler. De blev udviklet, forandret og forhandlet af den børnegruppe, der var i gang med spillet. Et eksempel er selve opbygningen af spillefladen. Konstruktionen startede med nogle få musemåtter, og samtidig med at fladen blev større, kom der flere regler og figurer. Spillet var faktisk ikke færdigt som spil, der kunne spilles af andre, da projektet var slut, men det blev spillet hele tiden. 
Udviklingen af brætspillet viser, hvordan leg og legekultur indgår i projektet. At legen er en afgørende faktor viser sig måske endnu tydeligere i følgende eksempel, som fik os til at indføre nye elementer i den pædagogiske struktur: De selvsamme piger, som kom og spurgte, om de måtte klippe hovederne af bamser, kom og viste de figurer, de havde lavet. Men når de blev spurgt om, hvad det var, de havde lavet, og om den ny figur hed noget eller kunne noget, kunne de ikke uden videre svare. Gaffatapen lagde op til en hurtig og usædvanlig konstruktion, hvor to ting, der i udgangspunktet intet havde med hinanden at gøre, pludselig kunne kombineres. Denne proces er tilsyneladende så interessant i sig selv, at der ikke nødvendigvis følger en færdig betydning eller fortælling med. Problemet var ikke, at pigerne ikke kunne svare. Problemet var, at de ikke have en måde at svare på. Ved bordene med spillet blev der både forhandlet, bygget og leget samtidig, men det kunne disse piger ikke. Der manglede simpelthen et sted, hvor de kunne lege med figurerne. Vi havde på det tidspunkt ikke tænkt et sådant sted ind i den pædagogiske struktur. Vi fandt så ud af at oprette både en Lager-udstiling og et Lege-laboratorium. Lager-udstillingen var et rullebord, hvor figurerne kunne stilles, hvis man nu ville lave noget mere legetøj, før man legede med det, der var lavet. Lager-udstillingen blev på den måde et sted at udstille legetøj, som kunne inspirere til nyt legetøj og en lagerplads indtil videre. Det sted, hvor legetøjet blev placeret, var altså ikke udtryk for et færdigt stykke legetøj, der skulle beundres, men et trin i en proces, der ikke behøvede at være færdig. Lege-laboratoriet var i vores tilfælde et stykke frit gulv foran en bred trappe lige ved siden af rullebordet. I lege-laboratoriet kunne vi bruge legetøjet og enten lege selv eller sammen med andre. Ideen med legelaboratoriet var enkel. Hvis man skal finde ud af, hvad et stykke legetøj betyder, og om det er godt at lege med, så må man lege med det. Forsøgsmetoden i et lege-laboratorium er altså leg. Resultatet af legen kan være, at legetøjet skal laves om med nye stumper og ny gaffatape. Et eksempel var Kanonborgen med de hundrede kanoner. Et par drenge havde placeret rigtig mange kanonløb på et stykke flamingo fra en computerkasse og forbundet disse kanoner via ledninger med en fjernkontrol. I legelaboratoriet viste det sig bare, at alle løbene vendte den samme vej, og at enhver fjende kunne komme ind bagfra. 


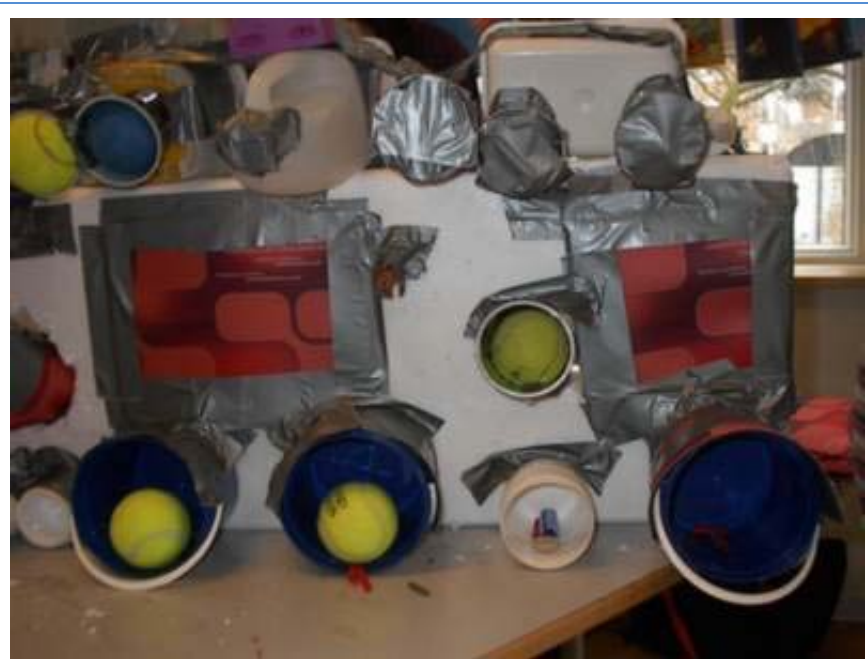

Billede 9. Kanonborgen med de hundrede kanoner. Skjult bag borgen er computerkontrollen til affyringen af kanonrørenes tennisbolde.

I lege-laboratoriet er det ikke vanskeligt at lære det nye legetøj bedre at kende og samtidig fortsætte med at lave mere legetøj. Brugen af legelaboratoriet gjorde det også nemmere at lave plakaterne til legetøjsbutikken, fordi undersøgelse af legetøjets brug og betydning havde været i gang siden de første prototyper blev lavet. Plakaterne var trykt i A3 og blev sat op bag det bord, som var legetøjsbutikken. Børnene havde taget billederne til plakaten med et digitalt kamera, de havde fundet på en overskrift og forklarende tekster, og sammen med en voksen ved en computer med et grafisk layoutværktøj blev billeder og tekst til en plakat i farver. Den sidste dag blev en syvende klasse inviteret ind i klassen for at kigge på butikkerne og spørge, hvad det var, de så og rørte ved. Her mødte syvende klassen børn i første klasse, som var noget nervøse ved at møde de store i skolen, men som også vidste, hvad det var, de havde i butikken. 


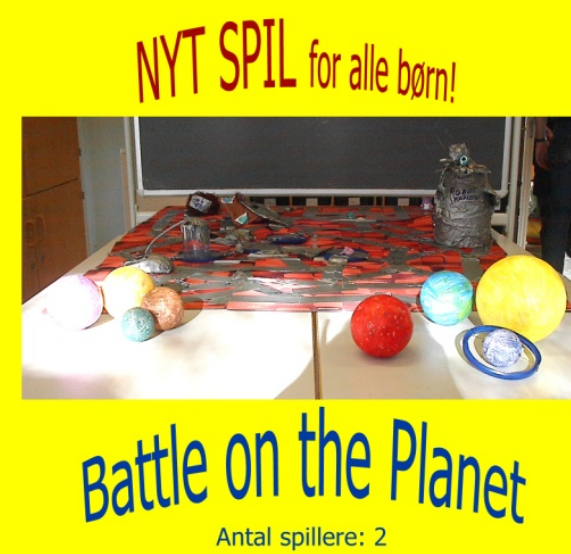

Et fantastisk spil, som handler om at ødelægge aliens Fjender kan også give få de bedste ting. købe våben, magier, rustninge og skjolde. Køb det bedste og gå i krig - det er det sjoveste!
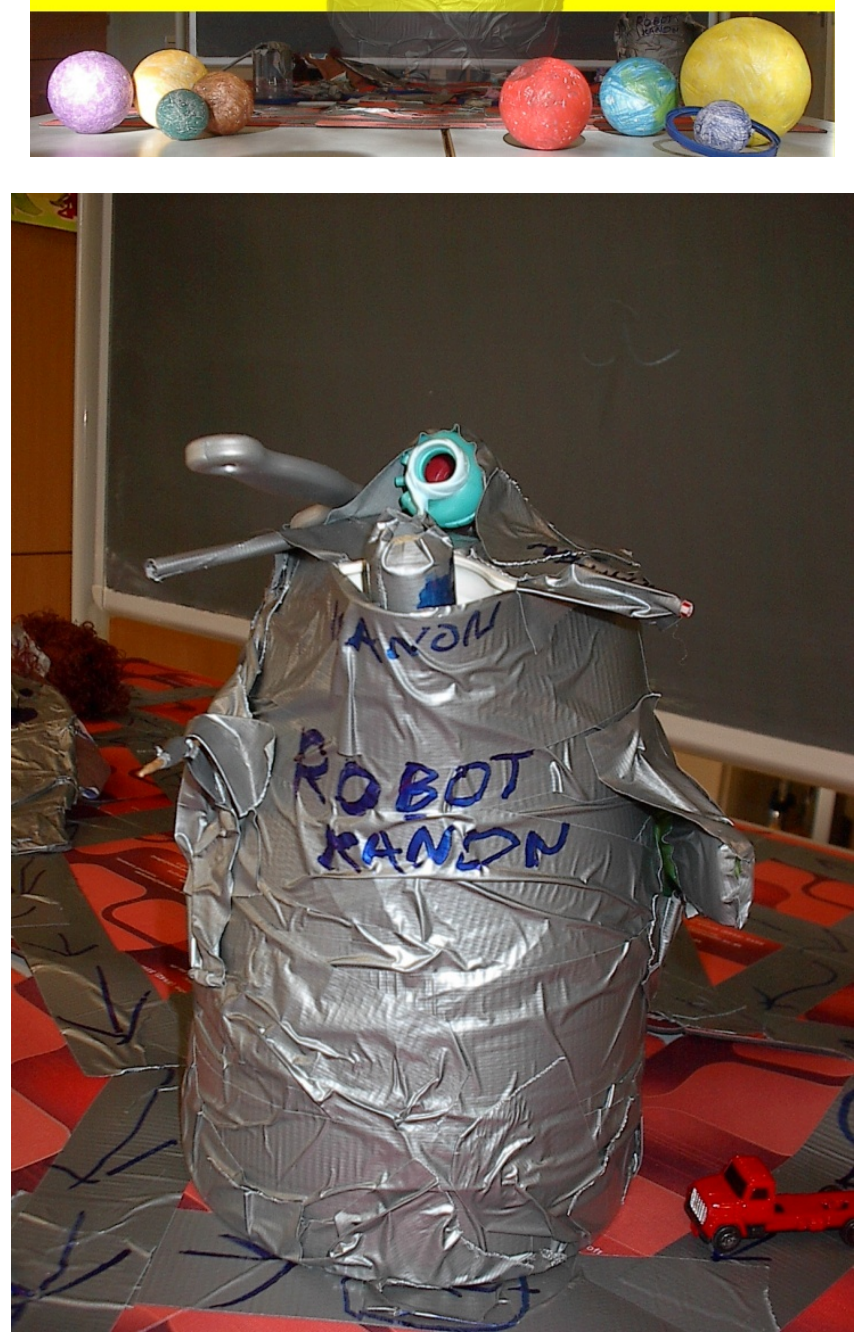

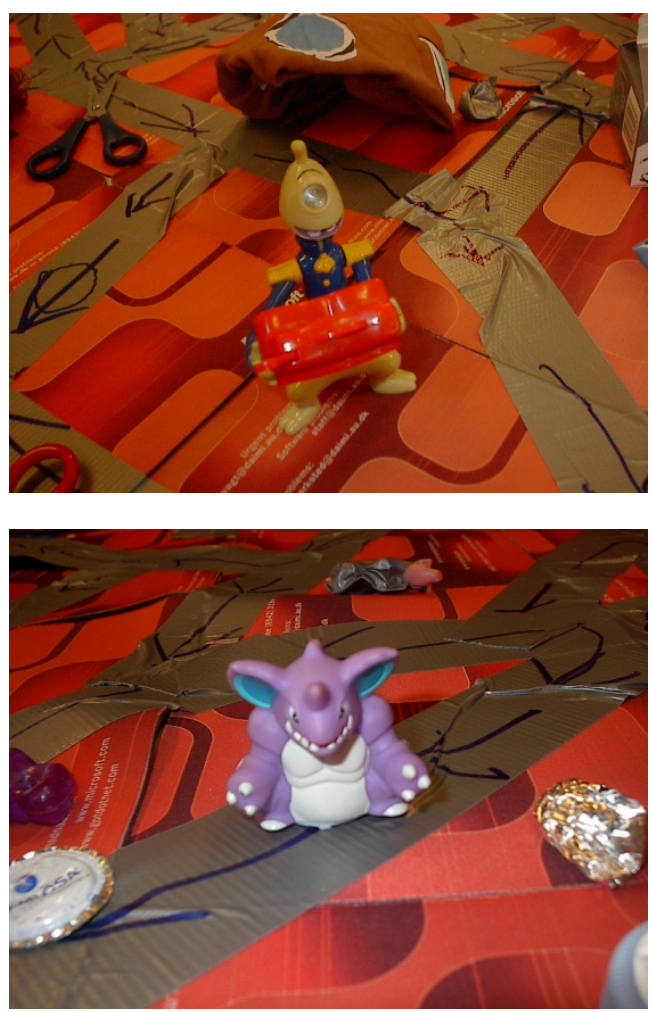

Billede 10. Planetspillet med de gode og onde og robotkanden med et kamera øje

I Opfind dit eget legetøj undersøgte børn og voksne, hvad det vil sige at opfinde og opdage i en konkret kontekst: Opfind legetøj ved hjælp af teknologisk skrot, kasseret legetøj og gaffatape og opdag, hvordan legetøjet kan indgå i leg. Den pædagogiske struktur fra Robotterne går sig en tur med klasseværelset som værksted med materiale fordelt i kasser blev udvidet med en Lager-udstiling, et Lege-laboratorium og en afrunding af aktiviteterne med at invitere en syvende klasse indenfor $\mathrm{i}$ legetøjsbutikkerne. Børn og voksne mødte teknologi i form af kasserede computere, tastaturer, mus, lommeregnere, mobiltelefoner og en enkelt brødrister. Det teknologiske skrot inspirerede til legetøj og lege med teknologisk indhold. Tastatur og mus styrede kanoner eller rumstationer og forestillinger om teknologi dukkede op i fortællinger om cyborg-dukker, rum-robotter og krige i fjerne galakser. I forløbet Opfind dit eget legetøj blev det endvidere klart, at vi tillod ting, som ellers ikke er tilladt hverken hjemme, i skolen eller SFO'en. Legetøjet og computerne må rent faktisk 
skilles ad. Havde børnene ikke spurgt, om de måtte klippe hovederne af tøjdyrene, og havde vi ikke tilladt det, havde vi nok ikke set Kaninkameraet eller mange af de andre væsner, som blev opfundet. Det at overveje, hvad der er tilladt og ikke tilladt i en pædagogik er altså bestemmende for, hvad der kommer til at foregå i en pædagogisk kontekst. I den pædagogik vi har kaldt Det eksperimenterende fællesskab er det tilladt at skille computere og legetøj ad, og det har været stærkt medvirkende til, at konkret indsigt i teknologi og forestillinger om teknologi blev en væsentlig del af samværet imellem børn og voksne i Opfind dit eget legetøj.

\section{Mikrobyen}

Med udgangspunkt i projektet Opfind dit eget legetøj fortsatte vi med den samme klasse men med et nyt projekt: Opfind din egen by. Her skulle klassen bygge en by med huse og veje af teknologisk skrot og kasseret legetøj. Hvordan byen nøjagtigt skulle se ud, og hvad den skulle indeholde, var ikke defineret på forhånd. Byen skulle udstilles i Steno Museets forhal sammen med en fotoserie, der viste arbejdsprocessen og små fortællinger fra byen. Da byen var ved at være klar til at blive udstillet, valgte børnene og vi at kalde den for Mikrobyen.

Mikrobyen indgik i en efterårsferieaktivitet på Steno Museet. Byen skulle inspirere besøgende til selv at forsøge sig med at opfinde legetøj eller dele til en by. På museet blev der derfor indrettet et værkstedsrum, hvor besøgende familier kunne gå på opdagelse i kasser med kasseret legetøj og teknologi-skrot og sætte sig ved borde med gaffatape, skruetrækkere og bidetænger spredt ud klar til brug. I forhallen blev der ud over Mikrobyen placeret et gråt tæppe med optegninger af et vejsystem og en havn men ellers ikke andet. Her kunne forældre og børn udstille de konstruktioner, de havde lavet i værkstedsrummet. På tæppet voksede en ny by frem hver dag, udstillingen varede. 

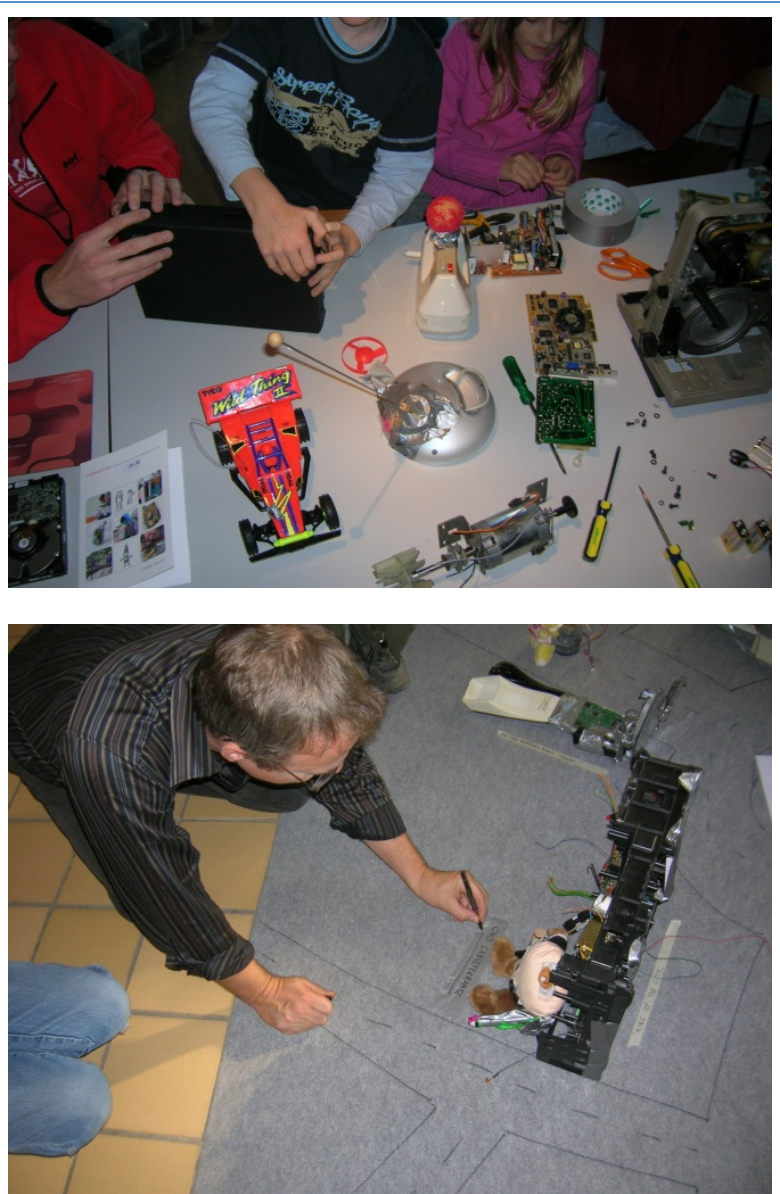

Billede 11. Værksted og by-tæppe på Steno Museet.

I forbindelse med dette projekt dukkede yderligere to nye aktiviteter op. Den ene dukkede op undervejs i selve forløbet i klassen. Ud af det teknologiske skrot kan man hente elementer, der stadigvæk virker. Det gælder f.eks. højtalere, lysdioder, ventilatorer eller dvd-skuffer. F.eks. kan en dvd-skuffe stadigvæk gå ind og ud, hvis en af dvd-skuffens motorer forbindes med ledninger til et batteri. Fra bamser og biler kan man hente komponenter, der lyser eller giver lyd fra sig. Det blev en selvstændig aktivitet ved et bord at sidde og lodde eller forbinde de forskellige komponenter. Et eksempel på brug af elementer, der stadig virker findes i Julestuen lavet af et par piger. I Mikrobyen var der en julestue, som solgte gaver hele året. Den bestod af et kabinet til en computerskærm fra en stationær computer. Kabinettet var blevet malet rødt indvendigt, udstyret med møbler og gaver og dekoreret med guirlander af lys lavet af serieforbundne lysdioder. Et andet eksempel findes i Blodteatret, som 
bestod af flere rammer til computerskærme. Blodteatret var et sted, hvor der blev vist uhyggelige film, og derfor havde blodteatret selvfølgelig flere blodige dukkehoveder med lysdioder som øjne eller næse.

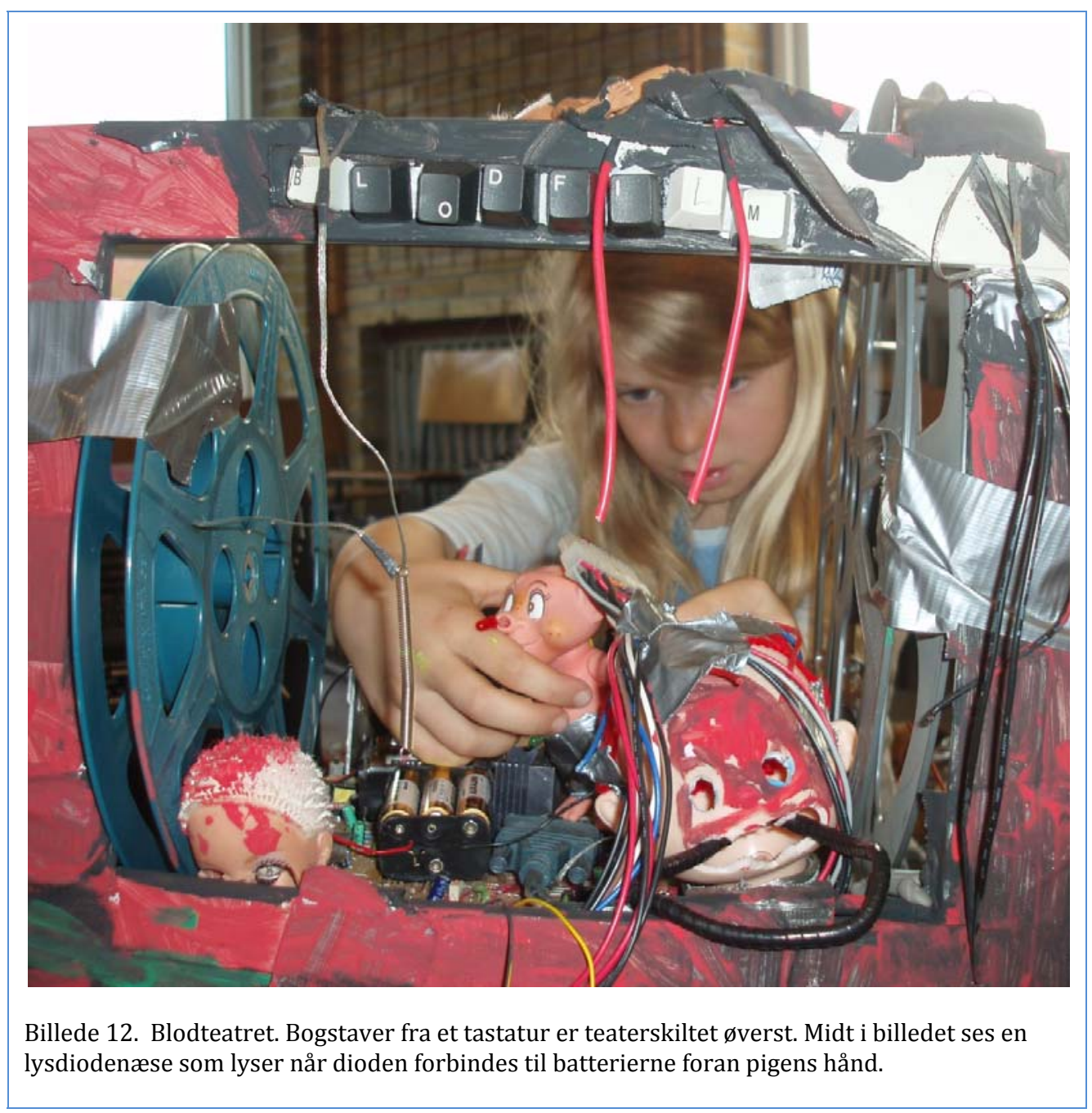

Den anden nye aktivitet dukkede op for at løse et praktisk problem under selve udstillingen på Steno Museet. Det ville blive vanskeligt at sikre konstante forsyninger af legetøj og skrot til de besøgendes aktiviteter. De besøgende på museet kunne derfor ikke få det opfundne legetøj med, som de netop havde lavet, selvom de formodentlig gerne ville. Derfor oprettede vi et hjørne i værkstedsrummet på museet, hvor det var muligt for besøgende at få taget et billede af det, de havde lavet. Stedet var indrettet på et bord op ad en væg. På bordet var der anbragt en bærbar computer, en printer samt et webcam. Et hvidt stykke papir var fastgjort $\mathrm{i}$ bordets ene ende og op ad væggen. Legetøjet kunne nu stilles på papiret, webcam 
kunne holdes, så legetøjet blev filmet med det hvide papir som baggrund, og på computerskærmen kunne billedet af legetøjet hele tiden ses, mens webcam blev anbragt i forskellige positioner i forhold til legetøjet. På den måde kunne flere samtidigt se legetøjet igennem et kamera og beslutte, hvornår der skulle tages billeder til print. I forhold til udstillingen og aktiviteten på Steno Museet virkede stedet efter hensigten. Det viste sig, at børnene meget gerne ville have taget billeder af deres nye legetøj og bagefter udstille legetøjet i den by, der voksede frem på tæppet. Samtidig blev print af billederne hængt op på væggen bag bordet, så der her opstod en udstilling i sig selv. Men det viste sig også, at det var muligt at føre en billedsamtale om legetøjet, der både inkluderede, hvad legetøjet hed og kunne og samtidig eksperimentere med vinkler og afstande, kameraet kunne anbringes i ved fotograferingen af legetøjet.

Begge aktiviteter er efterfølgende blevet faste elementer i den pædagogiske struktur, vi bygger det eksperimenterende fællesskab på. I teknologi-skrot og legetøj med elektriske dele kan børnene være med til at finde de komponenter, der virker og prøve at sætte dem sammen på forskellige måder. Man kan eksperimentere med at få flere ventilatorer til at blæse samtidigt. Man kan få en højtaler til at skratte ved at tilslutte et batteri og bevæge den ene ledning hen over højtalertilslutningen. En loddekolbe til at sætte komponenter og ledninger sammen er en fordel, men ikke en nødvendighed. Det er muligt at eksperimentere og finde ny brug for komponenterne. Et eksempel er Ventilatorbåden, der bestod af nogle aflange plastikstykker sat sammen med gaffatape med et batteri og en ventilator ovenpå. Denne konstruktion kunne reelt sejle med ventilatoren som en bagvendt propel, der skubbede båden frem. Et andet eksempel er Sukkermaskinen. Den bestod af en ventilator, der lå ned på et bord. En sukkerknald kan så føres ned i ventilatoren og blive lavet om til løst sukker. Derefter kan man lægge sukkeret op på en højtaler og få sukkeret til at danse, når højtaleren skratter. Til sidst kan sukkeret hældes i kaffen.

Bærbar computer med webcam og printer er blevet et sted, hvor der kan eksperimenteres med billeder. Webcam kan flyttes frem og tilbage. Der kan stå flere figurer inden for, i kanten af eller uden for billedrammen. Baggrunde og flader kan flyttes og skiftes ud. Billedet kan tages igen og 
igen, og der kan hele tiden eksperimenteres med nye opstillinger. Man kan lave en fortælling uden at trykke på udløseren, fordi webcam optager hele tiden og resultatet umiddelbart kan ses på skærmen. Man kan lave filmklip eller en billedserie, eller man kan blot prøve at tage billeder. Det afgørende er, at de, der trykker eller ændrer opstilling, hele tiden kan se, hvad de foretager sig. Et eksempel er Karamellegen, hvor en flad rektangulær kasse med karameller var blevet placeret foran en bærbar med webcam. Her udviklede der sig en leg, der involverede at en gruppe Pingu-figurer skulle henover alle disse karameller, mens de både blev filmet og taget billeder af med webcam.

I begge de nye aktiviteter er der plads til at undersøge materialer i en proces, der både har en selvstændig karakter, og som er en del af den samlede undersøgelse. En ventilator kan blive en båd, der kan udstilles og være med i en leg. Et billede kan printes ud, hænges op, klippes i stykker, tegnes på, stilles bag figurerne i en opstilling og blive taget billeder af på ny.

I både Opfind dit eget legetøj og Opfind din egen by var det meningen fra starten, at projekterne skulle føre til færdige produkter, som kunne vises til andre. Legetøjsbutikken med plakater blev vist frem på sidste dagen i Opfind dit eget legetøj og Mikrobyen med tilhørende fotoserie blev udstillet for besøgende på Steno Museet. For at de besøgende kunne få indblik i, hvordan byen var blevet til, og hvad der var i byen, forsynede børnene bygningerne med skilte og lavede fortællinger om byens historie som del af den ophængte fotoserie. Da vi efter udstillingen på museet skulle udstille byen på skolens bibliotek, begyndte børnene at lege med byen igen og lave om på det, de havde lavet til museet. For børnene var Mikrobyen altså ikke et færdigt produkt, som blot skulle flyttes og stilles op igen på skolens bibliotek. Den by, der blev udstillet på museet, var gjort færdig til udstilling, men under opstillingen på skolen begyndte legen igen. Mikrobyen forandrede sig, og det vil den nok gøre så længe legen er en mulighed. Allerede under legetøjsprojektet var det synligt, at der hele tiden kunne produceres nyt legetøj og nye fortællinger. Det samme gjaldt for Mikrobyen. Der blev bygget og skitseret huse, som igen blev skilt ad og brugt til noget andet. Så snart en bygning blev leget med, kunne den blive 
forandret. En bygning, et køretøj eller en figur kunne blive forladt til fordel for en anden bygning, køretøj eller figur.

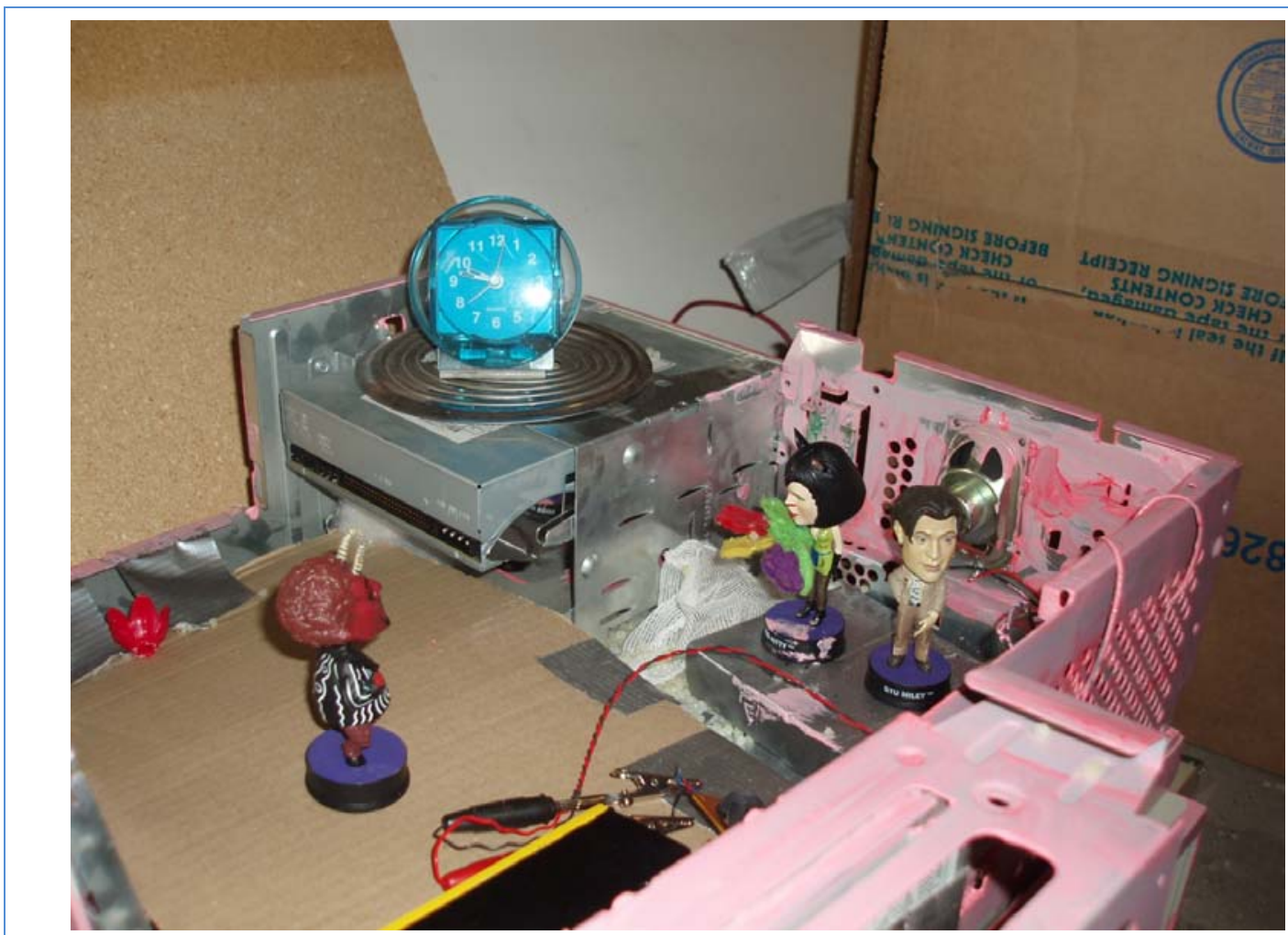

Billede 13. Rådhuset. Borgmesteren er ved at foretage en vielse af parret i den lyserøde bryllupssal.

Når legen inviteres indenfor i pædagogikken som kompetence i mødet med medier og teknologi, inviteres også forandringsprocessen indenfor. Forløbet med Mikrobyen varede lang nok tid til, at legens foreløbighed dukkede op. Når legen er slut, er udtrykket slut. Tilbage ligger resterne af et indhold og et formsprog, som var vigtigt der og da. Et eksempel var Militærbasen, der blev bygget op med kabinetter som mur udenom basen. Der blev ikke gjort meget ud af basen, murene blev ikke malet og heller ikke sat sammen med gaffatape. Set udefra lignede opstillingen mest af alt et lager af skrot, men set fra børnenes perspektiv var det noget helt andet. Denne base eksisterende kun i kort tid, så forsvandt den igen. De børn, der var i gang med basen, ville pludselig bygge en politistation et andet sted $\mathrm{i}$ byen. Basen blev faktisk til et lager af skrot, fordi en del af kabinetterne 
blev båret hen til et andet sted og brugt dér. Politistationen blev aldrig en del af byen på museet. Inden Mikrobyen blev udstillet, var politistationen blevet til en Pizzabar. På den anden side kunne børnene bruge meget tid på at gøre ting færdige, så de også set udefra lignede det, børnene forestillede sig. Et eksempel er Rådhuset, der som et dukkehus omhyggeligt blev malet, havde skiven fra et vækkeur som rådhus-ur og et flot udsmykket rum med muligheden for at blive gift. Alt dette skulle være færdigt, før det første par blev gift på rådhuset. Hvornår noget forlades, og hvornår noget gøres færdigt, afhænger af legen. Forholdet mellem proces og produkt skifter hele tiden. Legetøjsbutikken og Mikrobyen kan ses som de færdige produkter af en længerevarende proces, men kan ligeså vel ses som foreløbige nedslag i en proces, der fortsætter så længe nogen vil. Børnene var stolte af det, de havde gjort færdigt til udstillingen. F.eks. tog de billeder af deres huse med sig selv ved siden af, men de ville også gerne lave noget nyt. Svaret på denne udfordring er ikke nødvendigvis at ignorere legen eller at kanalisere den ind i en proces, der ender med et produkt. Svaret kunne være at etablere en pædagogik, hvor proces og produkt kan indgå i forskellige kombinationer undervejs. Et fællesskab hvor legen er en konstant og produktet en mulighed.

\section{Teknikleg}

Til udstillingen og efterårsaktiviteten på Steno Museet blev der udover Mikrobyen, værkstedet og det tomme gulvtæppe til dagens by også lavet en slags udstillingskatalog (Caprani og Thestrup 2005). Kataloget indeholder en beskrivelse af, hvordan Mikrobyen blev til, ideer til aktiviteter med teknologi-skot og kasseret legetøj samt overvejelser over den bagvedliggende pædagogik, vi havde brugt i forløbet med klassen. I titlen til udstillingskataloget brugte vi ordet Teknikleg om den type pædagogisk aktivitet, som vi havde gennemført i forløbet i klassen op til udstillingen. Vi valgte ordet for at understrege at en væsentlig del af aktiviteten går ud på at lege med teknik-stumper taget ud af eksisterende teknologi. Lysdioder, motorer, ledninger, bogstaver fra tastaturer, skærmrammer og computerkasser bliver brugt i konstruktionen af legetøj og byliv. Men ordet dækker også en pædagogik: en konkret opstilling med kasser, der 
indeholder teknologi-skrot, kasseret legetøj, værktøj og gaffatape; steder til at skille ad og sætte sammen igen, steder til midlertidigt lager og udstilling og endelig steder, hvor børn og voksne kan udfolde lege og fortællinger som en del af den fælles betydningsdannelse. Stumper af en eksisterende teknologi og legetøj indgår i et kredsløb, hvor ny teknologi og ny betydning kan opstå. Musemåtter bliver til veje, computerkabinetter til dukkehuse, printplader til byer set ovenfra og bamser til cyborgs. Computerne og bamserne er allerede, når de tages op af kasserne, et udtryk for en etableret brug. De er ikke et neutralt materiale uden rester af betydning. Men i den proces, hvor alting skilles ad og sættes sammen igen på nye måder, forvandles teknologien til ny teknologi. Computeren og bamsen bliver til et åbent materiale, der kan bruges til at skabe ny betydning. Lysdioder og pels er stumper, der kultiveres af børn og voksne i fællesskab. Når et kaninhoved sættes på et plastickamera, er det stadig kaninhoved og plastickamera, men det er også noget mere, som først kendes, når det er navngivet i en leg.

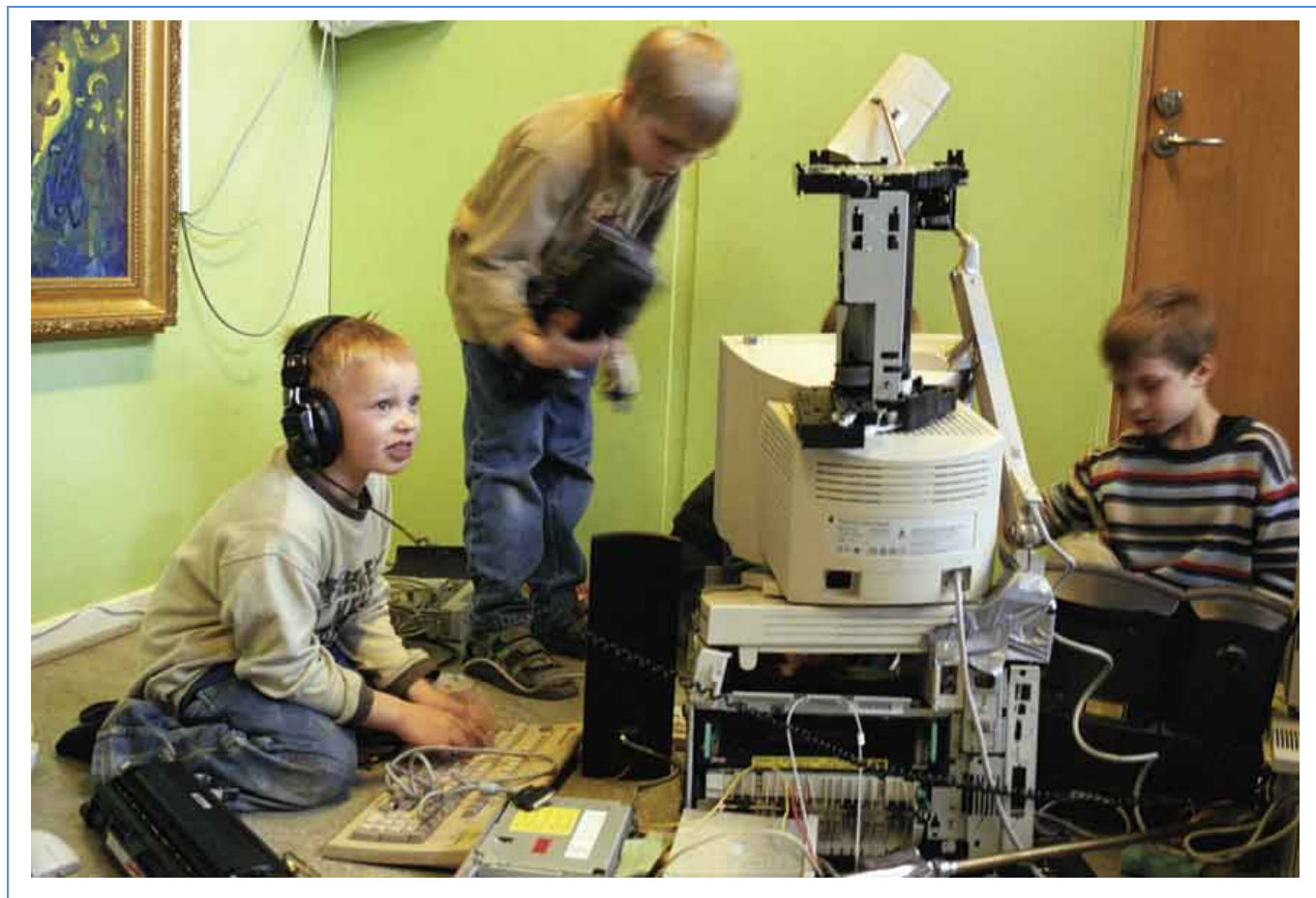

Billede 14. Teknikleg i en SFO. I legen forvandles teknologi-skrot til et kontrolcenter, hvor kampen mod angribende rumvæsner styres fra. 
I vores valg af ordet Teknikleg har vi skelet til en skelnen imellem teknik og teknologi, som bl.a. kommer til udtryk i Teknologirådets definition af teknologi: "Teknologi kan defineres som vores brug af teknik og de forhold, vi sætter op omkring dens anvendelse”, (Teknologirådet). Teknik er altså de komponenter, teknologi er sammensat af. Når vi skiller teknologi-skrot ad, står vi med teknik-stumper, som i eksperimentet, legen og fortællingen sættes sammen og bliver til ny teknologi.

\section{Det blå rum}

Projektet med børnehaveklassernes møde med CAVI's blue-screenteknologi startede ved en tilfældighed. I anden sammenhæng var vi tilstede i CAVI, da vi så nogle børn smutte ind ad døren til det blå studie på et tidspunkt, hvor det ikke blev brugt. Vi fulgte efter og fik et første indtryk af, hvordan børn kunne finde på at bruge rummet. Det blå studie er ca. $10 \mathrm{~m} \mathrm{x}$ $9 \mathrm{~m}$ og dermed næsten kvadratisk. De tre vægge er blå og den fjerde sort. På den sorte væg hænger et lærred på 2,40 m x 2,40 m, som skuespillere eller studieværter kigger på for at kunne følge med i, hvordan det redigerede billede ser ud. Ved den sorte væg er der to store kameraer på hjul. I selve rummet er der tre mindre kvadratiske blå kasser med en sidelængde på 0,50 m og en større kasse med en sidelængde på $1 \mathrm{~m}$. I studiet er der desuden blåt stof og blå flamingoplader. Lige ved siden af selve studiet findes et billedredigeringsrum. Uden om studie og billedredigeringsrum ligger forhal, kontorer og værksteder. Det var i et sådant blåt studie, vi så børn smutte ind for så at bevæge sig rundt i hele rummet, svøbe sig i det blå stof, gemme sig bag kasserne og kigge op på lærredet, så de kunne følge med i, hvordan de forsvandt på billedet. 


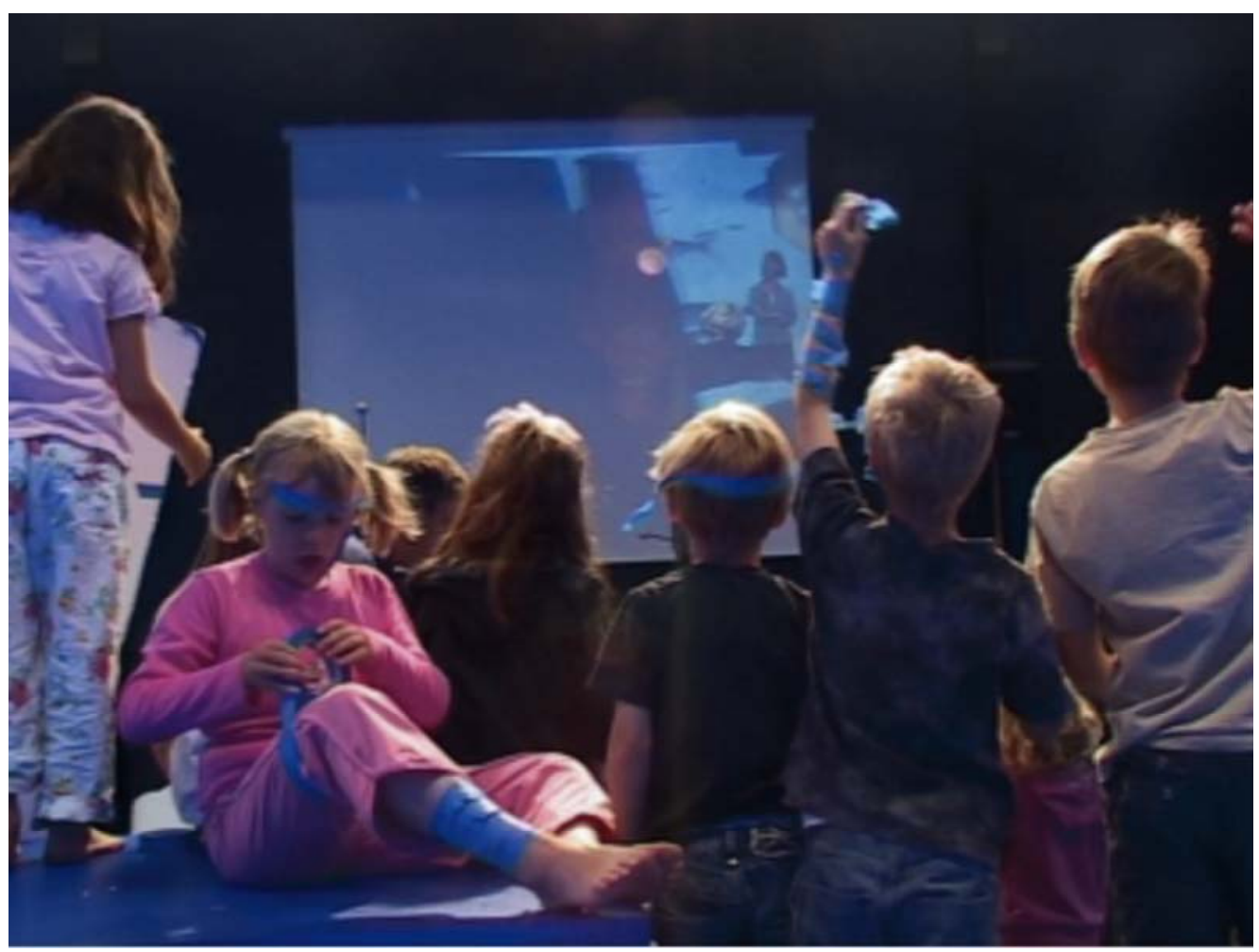

Billede 15. Børn i Det blå rum er optaget af at se sig selv og de andre på lærredet, mens de eksperimenterer med virkningen af det blå malertape.

Under forberedelserne til børnehaveklassernes møde med teknologien på CAVI foretog vi flere valg. Børnene skulle først være på skolen og arbejde med teknikleg. Vi ville etablere de sædvanlige introduktioner, fortællinger og muligheder for aktiviteter og på den måde etablere et eksperimenterende fællesskab, så vi kunne møde teknologien på CAVI gennem eksperimenter, leg og fortælling. De samme muligheder, der var på skolen i børnehaveklassen, skulle også være på CAVI. Det blå studie skulle indgå som en ny del af den praksis, der udspandt sig omkring skrot og legetøj. Vi oprettede de steder, vi før havde brugt i forskellige andre af vores projekter, og vi fortsatte arbejdet med at skabe forbindelser mellem mulighederne de enkelte steder. Både på skolen og på CAVI skulle det være muligt at tage billeder, printe billeder og male på dem. Det skulle være muligt at tegne og få tegningen overført til lærredet i det blå studie. Endelig skulle børnene kunne tage billeder med et kamera og få billeder overført til lærredet. Konsekvensen blev, at vi ikke kun brugte selve det blå studie, 
men inddrog forhallen, gange og trapper. Vi etablerede med andre ord en situation, hvor børnene ville kunne gå rundt i store dele af bygningen.

I to dage var børnene på skolen og lavede teknikleg sammen med os. Allerede her blev de introduceret til det blå studie. Vi fortalte om rummets størrelse, dets farve og lærredet på den ene væg. Vi forklarede, at man kunne blive usynlig i billedet på lærredet ved at tage blåt stof over sig. Børnene blev bedt om at lave tegninger, som de fik at vide ville komme op på lærredet i CAVI. Vi fortalte dem, at de ville kunne gå rundt i deres egne tegninger på billedet på lærredet. Vi bad dem huske at tage noget blåt tøj på for at vi kunne se hvilke blå farver, der ville forsvinde, og hvilke der ikke ville, når vi kom op i studiet. En hvid dobbeltdør blev inddraget i forsøget på at give dem en fornemmelse af rum, lærred og størrelse. Denne hvide dobbeltdør var på størrelse med lærredet i studiet og den blev brugt til at vise, hvor stort lærredet egentlig er og hvor stor tegningen og de selv ville være på lærredet. Vi kaldte studiet for Det blå rum, fordi vi betonede rummet, farven og de næsten magiske muligheder. Vi betonede ikke de tekniske sammenhænge.

Så mødte børnene CAVI. I forhallen uden for det blå studie kan man på en skærm følge med i det redigerede billede fra det blå studie. Foran skærmen fik børnene en kort introduktion. De sad på gulvet foran skærmen, mens vi gik ind og ud af det blå studie og viste børnene, hvordan vi kunne agere, som om vi var på en af deres tegninger. Derefter kom børnene ind i små grupper i en bestemt rækkefølge. Nogle blev ude ved skærmen, nogle sad inde i Det blå rum og kiggede på, og nogle agerede. Alle prøvede alt. Flamingoplader, stof, kasser og ruller med blå malertape. Efter denne introduktion fik alle lov til at prøve det, de ville i rummet. 


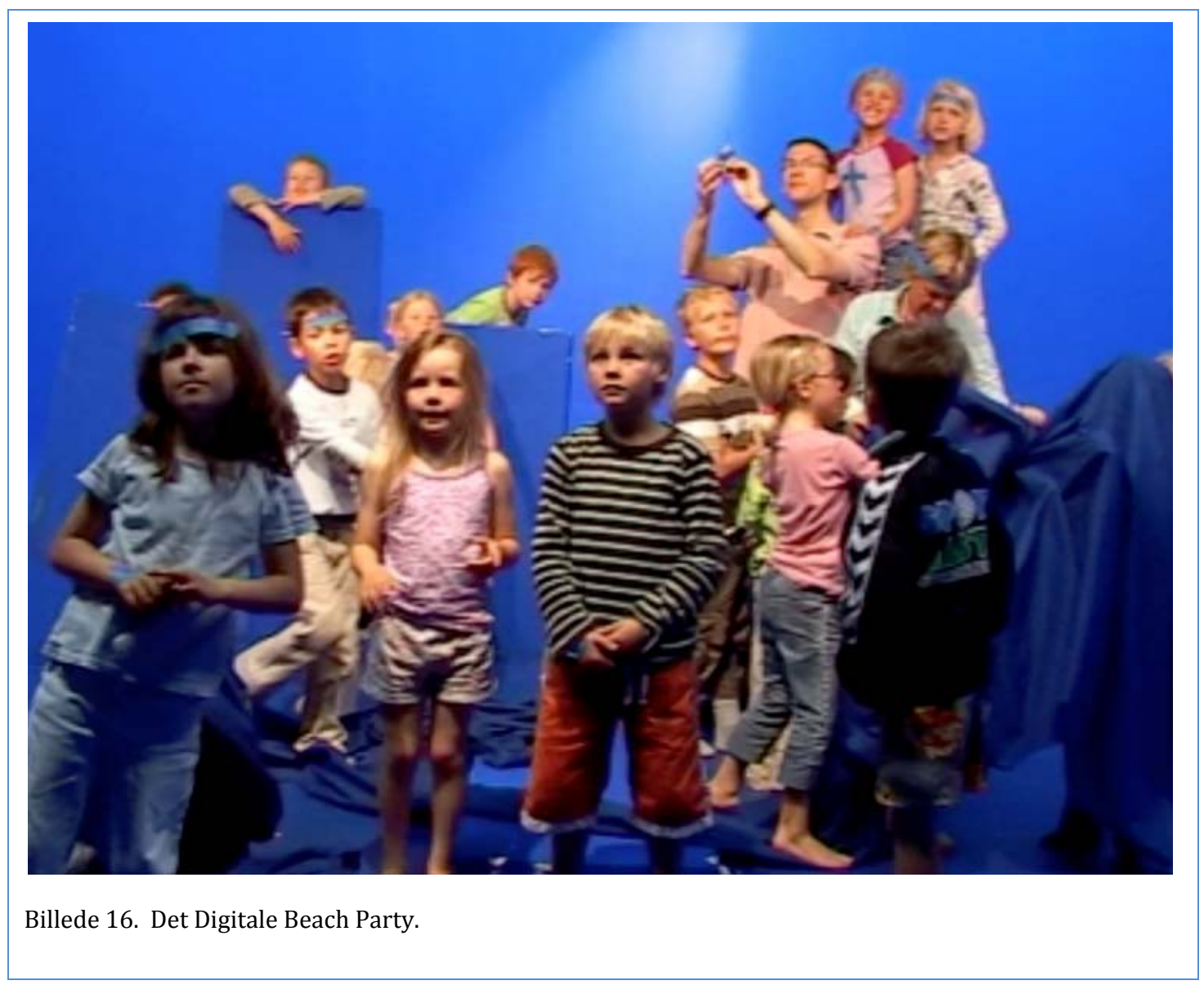

På den måde opstod det, vi har kaldt Det Digitale Beach Party. Alle bevægede sig rundt i rummet og prøvede de forskellige muligheder både sammen, i små grupper og hver for sig. Nogle koncentrerede sig om at kravle op og ned af kasserne. Nogle prøvede at blive usynlige ved at svøbe sig ind i stoffet eller stå bag flamingopladerne. Nogle viftede med hænderne og hoppede op og ned for at se, hvor de var i forhold til kameraet og dermed i forhold til billedet på væggen. Der blev pjattet, snakket, grinet og kigget på. Den blå malertape fik en særlig betydning. Den blå tape kunne bruges til alt fra at sætte et kryds på hånden, så man kunne se igennem det over at sætte tape for øjnene til at tape hele arme eller ben ind. Samtidig med alt dette dukkede den ene tegning efter den anden op, som børnene så på, hoppede i og forsvandt i. De billeder, der opstod på lærredet, var hele tiden under forandring. En tegning af en rød vulkan eller et foto af en legetøjslastbil var også billeder af børn, der hele tiden lavede om på dele af billederne. Intet felt på lærredet forblev det samme og mange felter på 
lærredet blev ændret samtidig. I det fysiske blå rum var femogtyve mennesker i fuld gang med at erobre et visuelt medie med kroppen, øjnene og en uimponeret lethed.

Da der var gået en halv time, forsvandt de fleste. Studiet stod tomt et stykke tid. Det digitale beach party var slut, og nye steder i bygningen blev interessante. Børnene begyndte at cirkulere, undersøge trapper og gange og finde et sted, de gerne ville være. Nogle brugte lang tid på f.eks. at tegne eller skille skrot ad, nogle ville hurtigt rundt og kigge på det hele. De enkelte steder blev forbundet på mindst tre forskellige måder. Der var de direkte forbindelser, som allerede eksisterede som mulighed, hvor børnene kunne gå ind i redigeringsrummet med en tegning og få den op på lærredet. Der var forbindelserne, som opstod, når børnene gik rundt mellem stederne og kiggede, snakkede og prøvede. Endelig var der forbindelser etableret af børnenes brug af de medbragte digitale kameraer og camcorders. Børnene gik rundt og prøvede kameraerne ved at tage billeder af andre børn, de steder, vi havde planlagt og andre dele af bygningen. Med disse kameraer gik de en form for Kamerature, hvor de både kunne blive en del af det, de så eller lade være. De kunne kontakte andre børn, tage billeder af dem, se billederne på kameraets display, følge med i forskellige begivenheder, lade kameraet hænge i hånden uden at bruge det eller tage billeder, der skulle lægges ind i computeren i redigeringsrummet. Børnenes kamerature gjorde det tydeligt at de forskellige steder og den bygning, alle befandt sig i, var steder, der kunne bruges, forbindes og forlades til fordel for andre steder eller begivenheder, der var vigtigere. Vi befandt os som pædagoger og lærere i en situation, hvor alt potentielt kunne ske, hvis nogen ville det. Det Digitale Beach Party var slut, men fortsatte i en ny form, hvor børnenes egen nysgerrighed var med til at afgøre, hvad det næste skridt bestod i. 

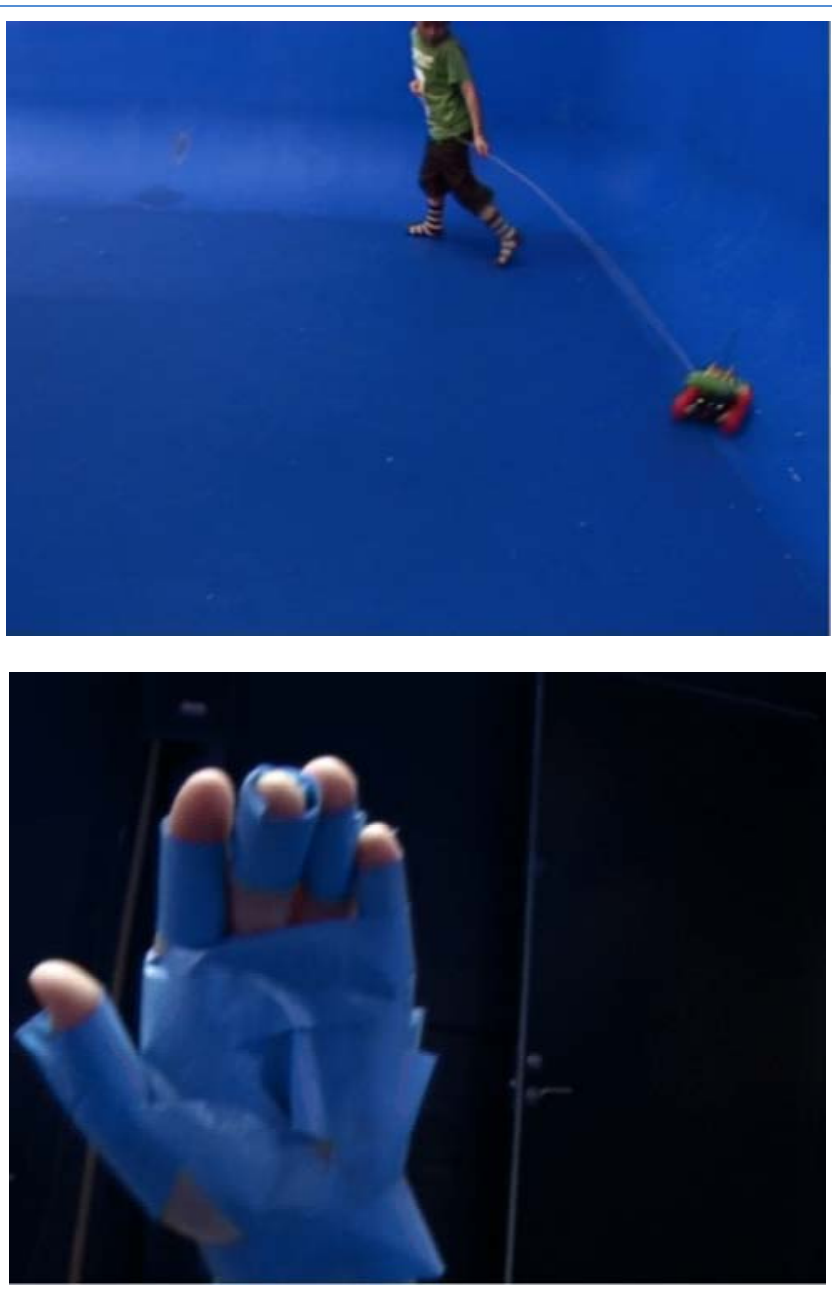

Billede 17. Det blå rum som legeplads, og malertape som kropsdekoration.

Et af de nye steder blev redigeringsrummet. Vi havde ikke forestillet os, at det ville blive et særligt afgørende sted i den pædagogiske struktur, men det skulle vise sig at være helt forkert. Det er her, baggrunde, studieværter og skuespillere placeres rigtigt i forhold til hinanden, og overgangene mellem baggrundene styres. Børnene kunne f.eks. bruge tid på at kigge på redigeringsrummets mange skærme og se de forskellige versioner af billedet på lærredet inde i studiet. De kunne styre og vælge baggrunde med et håndtag, en wiper, der kunne vippes frem og tilbage. På en computerskærm kunne de enten selv eller med hjælp af en tekniker vælge fotos eller tegninger, som skulle op på lærredet. De kunne komme løbende ind fra studiet og udbede sig et billede og gå ind igen eller blive siddende og kigge nærmere på de mange skærme. 


\section{Steder og samtidige processer}

Før vi besøgte CAVI, etablerede vi en navngivningsproces sammen med børnene. Helt enkelt var børnene med til at hente kasserne med skrot, legetøj og værktøj ind på skolen og med til at ændre de rum, vi havde til rådighed. De steder, vi oprettede i løbet af projektet, var børnene med til at navngive. Den bærbare med webcam fik betegnelsen Billedstedet. Bordet med loddekolbe, ledninger og batterier kom til at hedde Batteristedet. Der, hvor man kunne tegne, kom til at hedde Tegnestedet. Denne proces fortsatte på CAVI. Vi pointerede dette ved at kalde et tomt bord i forhallen på CAVI for Ikke-noget-endnu-stedet.

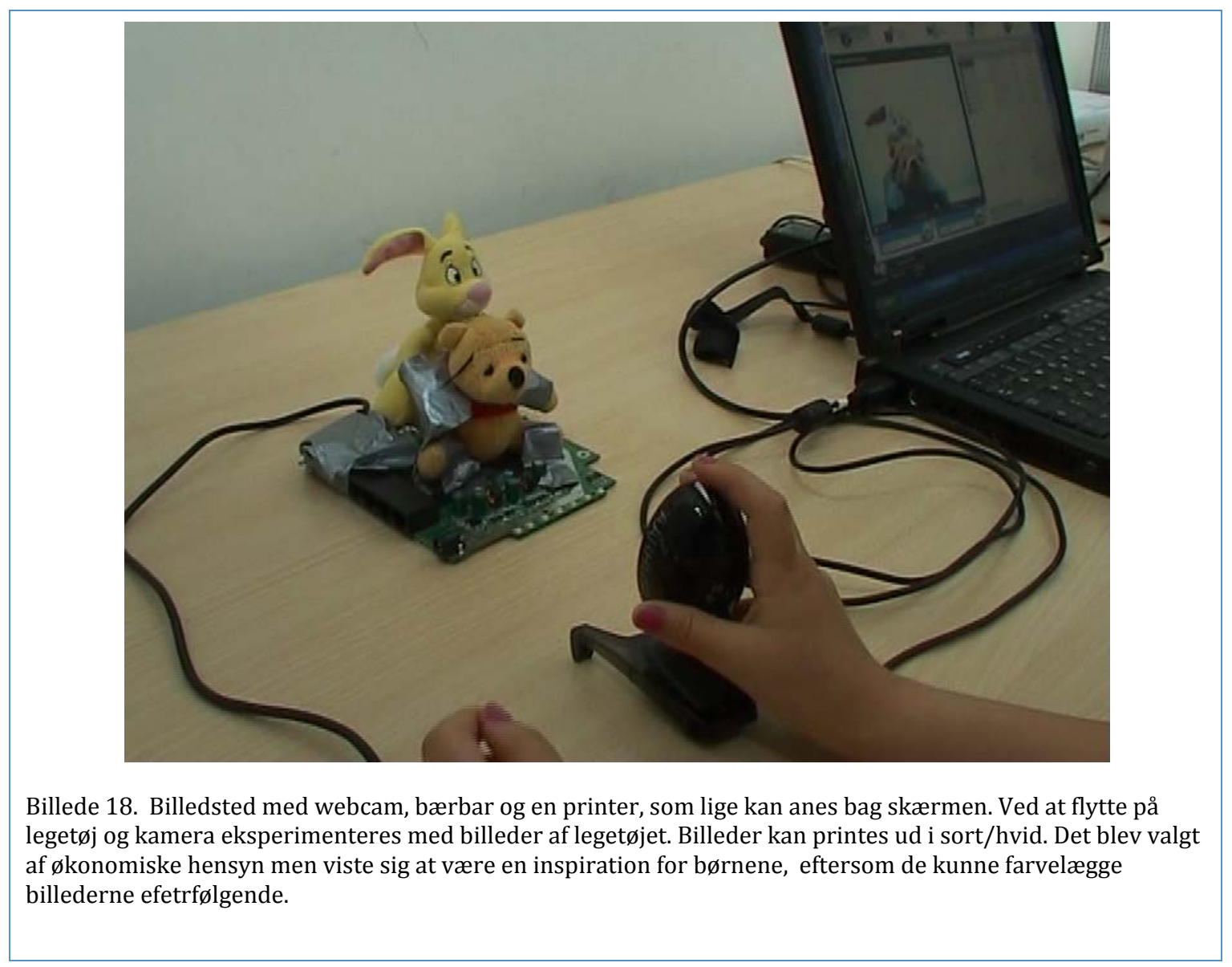


Når børnene navngav, ledte de efter et navn, som kunne fortælle, hvad man kunne foretage sig det enkelte sted. De opfangede hurtigt, at det var vigtigt i denne pædagogiske struktur, at man fandt på steder og navngav steder. Et eksempel var redigeringsrummet, der opstod undervejs. Et andet var da to børn selv lavede en købmandsbutik, hvor man kunne købe stumper af skrot, som de havde pillet ud. Vi opdagede det og pointerede over for dem og de andre børn, at her foregik noget interessant. At børnene var med på ideen, kunne vi konstatere den sidste dag tilbage på skolen, hvor to børn kom og hentede en af os for at vise os et sted, de selv havde lavet. Dette sted viste sig at være bag en reol på hjul, som var trukket en meter ud fra væggen. Bagved lå skrot og skruetrækkere. Set udefra var det ikke noget, men for de to børn var det et vigtigt sted.

Vi definerer et sted som en fysisk udstrækning, hvor der foregår en klart genkendelig og afgrænset aktivitet. For en, der kommer til stedet for første gang, skal der være et enkelt indstigningspunkt til en proces, hvor nye muligheder derefter kan vise sig. Vi definerer forbindelser mellem stederne som muligheden for transport af genstande og ideer og en bevægelse af børn, som kan påvirke, hvad der foregår det enkelte sted. Vi opfatter forholdet mellem de enkelte steder og forbindelserne mellem dem som en pædagogisk struktur, der udstrækker sig i tid og rum. Der kan foregå mange ting samtidigt, som kan påvirke hinanden, og der er ikke nødvendigvis nogen bestemt rækkefølge, hvori de forskellige steder skal besøges. Det betyder ikke, at det ikke er muligt at alle beslutter sig for at gøre den samme ting eller gå ind i en produktionsproces, der peger frem mod en færdig fortælling f.eks. på lærredet i Det blå rum eller i klasseværelset. Strukturen vil hele tiden bestå af steder, der for øjeblikket er vigtige, steder, som er helt nye, steder, som er kendte, steder, som opløses og forsvinder - og steder, som ingen kender endnu. I de samtidige processer i en sådan pædagogisk struktur med steder og forbindelser kan der opstå Brændpunkter, som ganske enkelt må undersøges. Det kan gælde alt fra at lave computermus, man kan trække i en snor, over at forsvinde på et lærred i det blå studie og til at tage billeder. 


\section{Voksenroller i det eksperimenterende}

\section{fællesskab}

Arbejdet med børns møde med medier og teknologi handler især om det reelle eksperiments plads i den pædagogiske struktur. Vi bestemmer ikke på forhånd, hvad børnene skal lave. Vi har ikke på forhånd som en del af den pædagogiske målsætning bestemt, hvilke betydninger der skal ligge i et givet stykke legetøj, en robot eller en tegning til lærredet i det blå studie. Den måde, hvorpå vi introducerer det enkelte projekt, den måde vi undervejs kommenterer, hvad der foregår og den, hvorpå vi fortæller, understøtter, at det reelle eksperiment er et fælles vilkår. Når vi opfinder et nyt stykke legetøj for øjnene af børnene, er situationen reel på den måde, at vi ikke på forhånd har bestemt, hvad dette stykke legetøj skal være. De fortællinger, vi skaber sammen med børnene, er heller ikke forberedt, men er i sig selv en undersøgelse af form og indhold, mens de laves. Vi gentager fortællingerne flere gange i løbet af det enkelte projekt og bygger videre på nye forslag.

Vi gør børnene opmærksomme på, hvordan det forholder sig. Vi fortæller dem, at vi ikke på forhånd bestemmer, hvordan f.eks. legetøj skal se ud og fortællinger forløbe. Vi kommenterer det, vi ser, og vi gør opmærksom på, at vi ser legetøj, tegninger, billeder og lege, som vi ikke har set før. Vi skiller selv teknologi og legetøj ad og sætter det sammen igen, vi tager billeder, vi er med til at undersøge, hvordan tegninger skal udformes, så de er gode at være i på lærredet i det blå studie, kort sagt vi deltager selv i de processeer, vi organiserer. Det betyder, at de voksne har flere forskellige roller i det eksperimenterende fællesskab. Vi har selvfølgelig den rolle at sørge for, at alle er med og har en mulighed for at bidrage til det, projektet handler om. Vi har også den rolle, at vi ved mere om fortællinger og teknologi, end børnene gør. Men vi har i ligeså høj grad den rolle, at vi ikke ved, og at vi sammen med børnene søger at få svar på de spørgsmål, som melder sig $\mathrm{i}$ processen. Endelig er det de voksne, som skaber rammerne for det eksperimenterende fællesskab. 


\section{Det eksperimenterende fællesskab - en}

\section{kulturel mødeplads}

Der ser ud til at være en tæt sammenhæng mellem børns legekultur og den pædagogiske struktur, som vi har arbejdet med. Når børn leger, bevæger de sig ubesværet mellem et fiktionsplan og et realplan. De forhandler og forandrer legens regler, legens indhold og betydningen af de genstande, der bruges undervejs i legen. De er fortællere af en fiktion, de selv deltager i. De tror ikke, at den fiktion, de er optaget af, er virkelig, men at den er vigtig at lege. Med legesignaler markerer de, hvornår og hvor legen foregår. Legereglerne er på én og samme tid helt de samme og helt foranderlige. Rammer for en leg huskes, opretholdes og udvikles af en børnegruppe i fællesskab. Børn ser ud til både at kunne fastholde en basal kode for en leg og at kunne ændre den, når det er nødvendigt. Det er børnegruppen som sådan, der tilsammen forhandler og leger den leg, der er vigtig. I tekniklegens hurtige prototyper ser noget lignende ud til at være på spil. Her kan betydningen af en genstand også etableres og ændres uden vanskeligheder og deltage i en børnegruppes betydningsdannelse. I den forstand er børn gode til at eksperimentere, hvis de får lov at lege i den pædagogiske kontekst, de er en del af. Hvis børn får mulighed for det, vil de som udgangspunkt anvende medier og teknologi som alt andet legetøj. Børns leg indeholder potentielt den overraskende brug af medier og teknologi.

Den legekultur, børnene udfolder i det eksperimenterende fællesskab, er ikke en nøje kopi af den legekultur, de udfolder i frikvarteret i skolen eller på legepladsen i SFO'en, men den er heller ikke fuldstændig løsrevet fra de legekulturelle fællesskaber, børn ellers er en del af. Børns legekultur eksisterer i konstant udveksling med det omgivende samfund og er en af de måder, børn er til stede i samfundet på. Det afgørende er, at børn, pædagoger og lærere mødes på en måde, der bl.a. giver plads til børns legekultur. Får børnene muligheden, henter de både legepraksis og legestrukturer fra deres hverdag ind i projektet. I en SFO har børn i høj grad mulighed for selv at bestemme, hvad de vil lave, med hvem og 
hvordan. Her tilegner og udfolder børnene en mængde kompetencer, de har brug for i legen, (Jessen, 2004). Hvis børnene ved, de må lege, og at de må bringe deres erfaringer ind fra dette helt almindelige børneliv, har de muligheden for at vise pædagoger og lærere, hvordan en leg skal leges, og hvordan medier og teknologi kan undersøges som en del af legen.

Pædagogen og læreren ved også noget om leg, fordi de til daglig observerer og organiserer børns leg, fordi de selv engang var børn, og fordi de måske er en del af en voksenkulturel legepraksis f.eks. som deltagere i rollespil eller sport. Muligheden eksisterer for, at pædagoger, lærere og børnene udvikler en fælles legepraksis, der fungerer, når de er sammen om medier og teknologi. Det betyder ikke, at børnene ikke kan lege for sig selv, men fællesskabet kan også indeholde den fælles leg baseret på børnenes legekultur og pædagogers og læreres legeforståelse. Det eksperimenterende fællesskab bliver en kulturel mødeplads, hvor viden og kunnen om leg med medier og teknologi udveksles imellem børn, pædagoger og lærere.

Under projekterne Opfind dit eget legetøj og Opfind din egen by var den kulturelle mødeplads tilstede, men underlagt et mål om at nå frem til en legetøjsbutik og en by. I det første forløb med LEGO-robotterne i 2002 var der ikke på forhånd planlagt noget produkt at nå frem til. Dengang vidste vi ikke ret meget om pædagogikken. I Det blå rum i 2007 og 2008 nærmede vi os en situation, hvor den pædagogiske struktur etablerede et fællesskab, hvor undersøgelser kan opstå ad hoc, fordi legen er permanent tilstede.

Det eksperimenterende fællesskab er altså et pædagogisk samvær imellem voksne og børn, hvor alt er på spil og konstrueres i samme bevægelse:

Pædagogikken, spørgsmålene, medierne, teknologien og samværsformerne. Ganske vist har de ansvarlige pædagoger og lærere sat rammer og har opbygget erfaringer med det, der kan foregå i et eksperimenterende fællesskab, men disse erfaringer stilles til rådighed for at opfange forandringer. Hvis et nyt eksperiment, en ny leg eller et nyt brændpunkt er undervejs, må den pædagogiske struktur indrette sig efter det for at kunne rumme dette eksperiment, denne leg eller dette brændpunkt. Det eksperimenterende fællesskab er altså også et pædagogisk laboratorium. Det er klart, at valget af LEGO-robotter, 
teknologiskrot, kasseret legetøj, gaffatape og blue-screen-teknologi har betydning for, hvad børn og voksne har lavet i projekterne. Det er også klart, at valg af tema såsom robotter, opfinde legetøj og byer spiller ind, men det er først og sidst pædagogikken, der afgør, hvad børnene får mulighed for at foretage sig i mødet med medier og teknologi.

\section{Litteratur}

Caprani, Ole og Klaus Thestrup (red.) (2005). Teknikleg - et inspirationskatalog til opfindsomme børn og voksne, Steno Museet, 2005, Århus, http://www.teknikleg.cs.au.dk/TeknikLEG.pdf

Caprani, Ole, Lars Henningsen, Klaus Thestrup (red.) (2007). I det blå rum medieleg med skrot og kamera, DVD, Århus, ikke udgivet

CAVI, Center for Avanceret Visualisering og Interaktion, http://cavi.dk

Henningsen, Lars (2002). Robotterne går sig en tur, Narrativ dokumentationsvideo, ZipZap Video, Århus,

http://www.teknikleg.cs.au.dk/Robotterne_gaar_en_tur.mov

Jeppesen, Hanne Algot og Wøldiche, Jesper (red.) (2002). Når robotterne går sig en tur. Projektpublikation, Multimedieværkstedet, Kulturcenter Huset, Århus.

Jessen, Carsten (2004). Uformelle læringsrum, Danmarks Pædagogiske Universitet.

Mouritsen, Flemming (1996). Legekultur. Essays om børnekultur, leg og fortælling, Odense Universitetsforlag

Poulsgaard, Hanne Mette (2004). Opfind dit eget legetøj, fotoserie, hænger på Katrinebjergskolen i Århus, 2004.

Teknologirådet, http://www.tekno.dk/subpage.php3?page=statisk/dk_profil.php3\&top pic=om_os, besøgt september 2009

3. b på Katrinebjergskolen og Claus Vammen Jacobsen (2005): Mikrobyen, hæfte, ikke udgivet.

3. b på Katrinebjergskolen og Klaus Thestrup (2005). Fortællinger fra Mikrobyen, Fotoudstilling på Steno Museet. 